\title{
A fertile peatland forest does not constitute a major greenhouse gas sink
}

\author{
A. Meyer $^{1}$, L. Tarvainen ${ }^{2}$, A. Nousratpour ${ }^{1}$, R. G. Björk ${ }^{3}$, M. Ernfors ${ }^{4}$, A. Grelle ${ }^{5}$, Å. Kasimir Klemedtsson ${ }^{3}$, \\ A. Lindroth ${ }^{6}$, M. Räntfors ${ }^{1}$, T. Rütting ${ }^{3}$, G. Wallin ${ }^{1}$, P. Weslien ${ }^{3}$, and L. Klemedtsson ${ }^{3}$ \\ ${ }^{1}$ Department of Biological and Environmental Sciences, University of Gothenburg, Gothenburg, Sweden \\ ${ }^{2}$ Department of Forest Ecology and Management, Swedish University of Agricultural Sciences, Umeå, Sweden \\ ${ }^{3}$ Department of Earth Sciences, University of Gothenburg, Gothenburg, Sweden \\ ${ }^{4}$ Department of Agrosystems, Swedish University of Agricultural Sciences, Alnarp, Sweden \\ ${ }^{5}$ Department of Ecology, Swedish University of Agricultural Sciences, Uppsala, Sweden \\ ${ }^{6}$ Department of Physical Geography and Ecosystems Science, Lund University, Lund, Sweden
}

Correspondence to: A. Meyer (astrid.meyer@yahoo.de)

Received: 6 February 2013 - Published in Biogeosciences Discuss.: 13 March 2013

Revised: 4 October 2013 - Accepted: 9 October 2013 - Published: 28 November 2013

\begin{abstract}
Afforestation has been proposed as a strategy to mitigate the often high greenhouse gas (GHG) emissions from agricultural soils with high organic matter content. However, the carbon dioxide $\left(\mathrm{CO}_{2}\right)$ and nitrous oxide $\left(\mathrm{N}_{2} \mathrm{O}\right)$ fluxes after afforestation can be considerable, depending predominantly on site drainage and nutrient availability. Studies on the full GHG budget of afforested organic soils are scarce and hampered by the uncertainties associated with methodology. In this study we determined the GHG budget of a spruce-dominated forest on a drained organic soil with an agricultural history. Two different approaches for determining the net ecosystem $\mathrm{CO}_{2}$ exchange (NEE) were applied, for the year 2008, one direct (eddy covariance) and the other indirect (analyzing the different components of the GHG budget), so that uncertainties in each method could be evaluated. The annual tree production in 2008 was $8.3 \pm 3.9 \mathrm{tC} \mathrm{ha}^{-1} \mathrm{yr}^{-1}$ due to the high levels of soil nutrients, the favorable climatic conditions and the fact that the forest was probably in its phase of maximum $\mathrm{C}$ assimilation or shortly past it. The $\mathrm{N}_{2} \mathrm{O}$ fluxes were determined by the closed-chamber technique and amounted to $0.9 \pm 0.8 \mathrm{tC}_{\mathrm{eq}} \mathrm{ha}^{-1} \mathrm{yr}^{-1}$. According to the direct measurements from the eddy covariance technique, the site acts as a minor GHG sink of $-1.2 \pm 0.8 \mathrm{t} \mathrm{C}_{\mathrm{eq}} \mathrm{ha}^{-1} \mathrm{yr}^{-1}$. This contrasts with the NEE estimate derived from the indirect approach which suggests that the site is a net GHG emitter of $0.6 \pm 4.5 \mathrm{tC}_{\mathrm{eq}} \mathrm{ha}^{-1} \mathrm{yr}^{-1}$. Irrespective of the approach ap-
\end{abstract}

plied, the soil $\mathrm{CO}_{2}$ effluxes counter large amounts of the $\mathrm{C}$ sequestration by trees. Due to accumulated uncertainties involved in the indirect approach, the direct approach is considered the more reliable tool. As the rate of $\mathrm{C}$ sequestration will likely decrease with forest age, the site will probably become a GHG source once again as the trees do not compensate for the soil $\mathrm{C}$ and $\mathrm{N}$ losses. Also forests in younger age stages have been shown to have lower $\mathrm{C}$ assimilation rates; thus, the overall GHG sink potential of this afforested nutrient-rich organic soil is probably limited to the short period of maximum $\mathrm{C}$ assimilation.

\section{Introduction}

After drainage, organic soils continuously lose $\mathrm{CO}_{2}$ to the atmosphere, irrespective of their use as agricultural or forest land. Hence, such soils contribute to global warming (Couwenberg et al., 2011). For Sweden, it has been estimated that organic soils used for agriculture release 6-10\% of the total national emission of greenhouse gases (GHG) (Kasimir Klemedtsson et al., 1997; Berglund and Berglund, 2010), despite the fact that only $5-10 \%$ of agricultural land is on such soils. These emissions are primarily a result of drainage, which increases soil aeration and consequently organic matter mineralization, resulting in emissions of carbon $(\mathrm{C})$ - and nitrogen $(\mathrm{N})$-rich atmospheric trace gases (e.g. 
Kasimir Klemedtsson et al., 1997; Maljanen et al., 2010). The main GHG is $\mathrm{CO}_{2}$ with reported emissions of 0.8 $15.8 \mathrm{tC} \mathrm{ha}^{-1} \mathrm{yr}^{-1}$ (Nykänen et al., 1998; Maljanen et al., 2004, 2007; see also review by Alm et al., 2007, and Maljanen et al., 2010), but $\mathrm{N}_{2} \mathrm{O}$ emissions can also be high (2$37 \mathrm{~kg} \mathrm{~N} \mathrm{ha}^{-1} \mathrm{yr}^{-1}$ : Höper et al., 2002; Kasimir Klemedtsson et al., 2009). Methane $\left(\mathrm{CH}_{4}\right)$ emissions from drained organic soils are usually of limited importance (Huttunen et al., 2003; Maljanen et al., 2003a; von Arnold et al., 2005b; Alm et al., 2007; Kasimir Klemedtsson et al., 2009). Afforestation has been discussed as a mitigation strategy to reduce GHG emissions from agricultural soils because it is assumed that the reduction in fertilizer application and management activities, and especially the increase in plant $\mathrm{C}$ accumulation, will convert the ecosystem into an overall GHG sink (Watson et al., 2000; Hargreaves et al., 2003).

Forests on drained organic soils have long been assumed to constitute an overall GHG sink, even when the soil acts as a C source; this is because the $\mathrm{C}$ accumulation by the trees is assumed to compensate for soil losses (Minkkinen et al., 1999; Minkkinen et al., 2002; Hargreaves et al., 2003). Previous studies, however, indicate that drained organic soils can be responsible for considerable $\mathrm{CO}_{2}$ and $\mathrm{N}_{2} \mathrm{O}$ emissions for several years after afforestation $\left(\mathrm{CO}_{2}\right.$ : up to $5.2 \mathrm{tCha}^{-1} \mathrm{yr}^{-1}$, Alm et al., 2007) because the soil fertility, the abundant availability of $\mathrm{C}$ substrates, and the low water table favor microbial decomposition (Maljanen et al., 2003b; von Arnold et al., 2005b). Thus, high soil C and $\mathrm{N}$ losses potentially outweigh $\mathrm{C}$ accumulation by the trees (Alm et al., 2007).

The soil $\mathrm{CO}_{2}$ emissions from drained organic forest soils are reported within the Land Use and Land Use Change and Forestry (LULUCF) sector for UNFCCC (United Nations Framework Convention on Climate Change) and Kyoto submissions (http://unfccc.int/national_reports/annex_i_ ghg_inventories/items/2715.php). The Swedish National Inventory Report (NIR) (2012) submitted to the UNFCCC uses emission factors (EFs) for $\mathrm{CO}_{2}$ of 3.0 and $1.9 \mathrm{tC} \mathrm{ha}^{-1} \mathrm{yr}^{-1}$ for well-drained and poorly drained forest soils, respectively, based on the work of von Arnold (2004). However, these emissions (in total $9.5 \mathrm{Tg}$ ) are subtracted from the uptake of $\mathrm{CO}_{2}$ by the net forest production $(29 \mathrm{Tg})$, a much larger flux. As a consequence the soil emissions are not clearly made visible in the NIR. So far, $\mathrm{N}_{2} \mathrm{O}$ emissions from drained organic forest soils have not been included in the Swedish NIR. This was decided by the Swedish Environmental Protection Agency according to the Conference of the Parties (No 9), arguing that reporting of $\mathrm{N}_{2} \mathrm{O}$ emissions due to forest drainage is optional (UNFCCC decision 13/CP.9). However, the Intergovernmental Panel on Climate Change (IPCC) Good Practice Guidance (2003, www.ipcc-nggip.iges.or.jp/public/gp/ english/) recommends using EFs of 0.1 and $0.6 \mathrm{~kg} \mathrm{~N}_{2} \mathrm{O}$ $\mathrm{N} \mathrm{ha}^{-1} \mathrm{yr}^{-1}$ for nutrient-poor and nutrient-rich soils, respectively. The same default EFs from forests on drained organic soils are also included in the 2006 IPCC Guidelines. These will be the mandatory guidelines for future NIR accounting, and the default EFs are in the process of being updated by the IPCC Wetlands Supplement, which will be published in autumn 2013. However, great uncertainty exists with regard to the precision of the recommended $\mathrm{N}_{2} \mathrm{O}$ EFs so far, which is mainly due to the scarcity of available measurements, missing consideration of emission predictors, and inaccuracies in up-scaling of emissions (von Arnold et al. 2005a). As a consequence, the calculation of total GHG budgets for drained organic forest soils based on IPCC Good Practice Guidance (2003) is rather unclear. In addition, existing studies have rarely taken emissions of all GHGs at a site into account, so that there is much uncertainty with regard to the estimation of GHG budgets based on empirical data (Maljanen et al., 2010). More data and a better process understanding are needed to fill this gap.

To our knowledge only Lohila et al. (2011) have investigated all major GHGs $\left(\mathrm{CO}_{2}, \mathrm{~N}_{2} \mathrm{O}, \mathrm{CH}_{4}\right)$ from a forest on a drained organic soil for a full year, although short-term studies with specific focus on frost events and clear-cutting exist (Mäkiranta et al., 2010; Pihlatie et al., 2010). Using micrometeorological measurements to determine the $\mathrm{CO}_{2}$ flux and chamber measurements to quantify the $\mathrm{N}_{2} \mathrm{O}$ and $\mathrm{CH}_{4}$ fluxes, Lohila et al. (2011) found that a pine forest on a drained organic soil was an intermediate $\mathrm{C}$ sink, in which $\mathrm{N}_{2} \mathrm{O}$ and $\mathrm{CH}_{4}$ only had a minor impact on the total GHG budget. However, this site had not been in agricultural use previously and had a high soil $\mathrm{C}$ : $\mathrm{N}$ ratio (34-41), which is why low $\mathrm{N}_{2} \mathrm{O}$ emissions could be expected (Klemedtsson et al., 2005).

The soil $\mathrm{N}$ content, which is often high in former agricultural soils, seems to be a key indicator for the soil $\mathrm{C}$ balance (Minkkinen et al., 1999) and for $\mathrm{N}_{2} \mathrm{O}$ emissions of organic soils in the hemiboreal to boreal regions (Klemedtsson et al., 2005; Mäkiranta et al., 2007). Klemedtsson et al. (2005) found a clear correlation between soil $\mathrm{C}: \mathrm{N}$ and $\mathrm{N}_{2} \mathrm{O}$ emissions, which was subsequently used by Ernfors et al. (2008) to extrapolate $\mathrm{N}_{2} \mathrm{O}$ emissions to the country level. They found that afforested organic soils are responsible for $15 \%$ of the total Swedish anthropogenic $\mathrm{N}_{2} \mathrm{O}$ emissions, but this figure has not yet been used in the UNFCCC reports. Nevertheless, the release of $\mathrm{N}$ due to mineralization is primarily governed by the water table depth so that the drainage status is a key factor (Martikainen et al., 1993). Therefore, drained nutrient-rich afforested organic soils are potentially large sources of GHGs.

The GHG budgets of forests on drained organic soils are uncertain due to both the scarcity of studies and the uncertainties associated with existing methods for determining the GHG budget. The most frequently used indirect approach is to quantify the soil GHG fluxes using the chamber method and to relate these to the biomass production of the trees as determined by biomass functions (e.g. Marklund et al., 1989; Minkkinen et al., 2001; Jalkanen et al., 2005). The chamber technique has been shown to give different results depending on the equipment and chamber design used (Pumpanen et al., 2004; Christiansen et al., 2011). Despite this, a recent study 
by Ojanen et al. (2012) on the $\mathrm{C}$ budget of peatlands identifies the chamber technique as a useful tool for GHG inventories, but only when the associated uncertainties are tolerable. However, the net ecosystem $\mathrm{CO}_{2}$ exchange (NEE) can only be measured by the use of micrometeorological methods (Mäkiranta et al., 2007; Lohila et al., 2007, 2011). A drawback of this method is that measurements are laborious to set up and cost-intensive. Most important, the technique does not work well under highly stable atmospheric conditions (Moffat et al., 2007; Vickers et al., 2012). The biggest problem with eddy covariance measurements is that the source area (footprint) of the flux varies dynamically in relation to turbulent conditions; consequently footprint areas are generally smaller during days than during nights.

In view of the need to quantify further the GHG budget of forests on nutrient-rich drained organic soils, we investigated the major GHG fluxes of a drained organic soil in southwestern Sweden. The site has previously been used for agriculture but has been afforested with Norway spruce for about $60 \mathrm{yr}$. The GHG budget was determined for one year by estimating the ecosystem fluxes of $\mathrm{N}_{2} \mathrm{O}, \mathrm{CH}_{4}$ and the NEE. To quantify the NEE, two different approaches were used: direct measurement using the eddy covariance technique (EC) and an indirect approach using the chamber technique and flux balance calculations. This allowed us to compare the two approaches with regard to their limitations and uncertainties and to analyze the effect on the overall budget.

\section{Material and methods}

\subsection{Site description}

The study was conducted in a forest stand on a drained organic soil in the Skogaryd research catchment $\left(58^{\circ} 23^{\prime} \mathrm{N}\right.$, $12^{\circ} 09^{\prime} \mathrm{E}$ ) in southwestern Sweden (Klemedtsson et al., 2010). The former mesotrophic fen was drained in the 1870 s and was used for agriculture until 1951 when it was afforested. During the study period, the stand density was approximately 1000 trees ha ${ }^{-1}$. Norway spruce, Picea abies (L.) Karst., dominated the stand ( $82 \%$ of the basal area, BA) but Scots pine, Pinus sylvestris L. (13\% of BA), and Silver birch, Betula pendula Roth (5\% of BA), were also present. The dominant and co-dominant Norway spruce trees were $22-25 \mathrm{~m}$ in height and the average LAI was $5.1 \mathrm{~m}^{2} \mathrm{~m}^{-2}$ at the bottom of the living crown in May 2007 (Dewar et al. 2012). The field vegetation was dominated by bryophytes with sparse vascular plants, including species such as Luzula pilosa and Oxalis acetosella. The soil was classified as a histosol (IUSS 2006) with the organic layer more than $1 \mathrm{~m}$ deep and a $\mathrm{C}$ content of $116 \pm 16 \mathrm{tC} \mathrm{ha}^{-1}$ in the upper $50 \mathrm{~cm}$. The average soil $\mathrm{pH}$ in the upper $20 \mathrm{~cm}$ was between 4.4 and 4.6 (Ernfors, 2009). Soil properties were determined in October 2007; the soil organic matter content was $85 \%$ in the upper $15 \mathrm{~cm}$ and $87 \%$ between 15 and $40 \mathrm{~cm}$. The site is
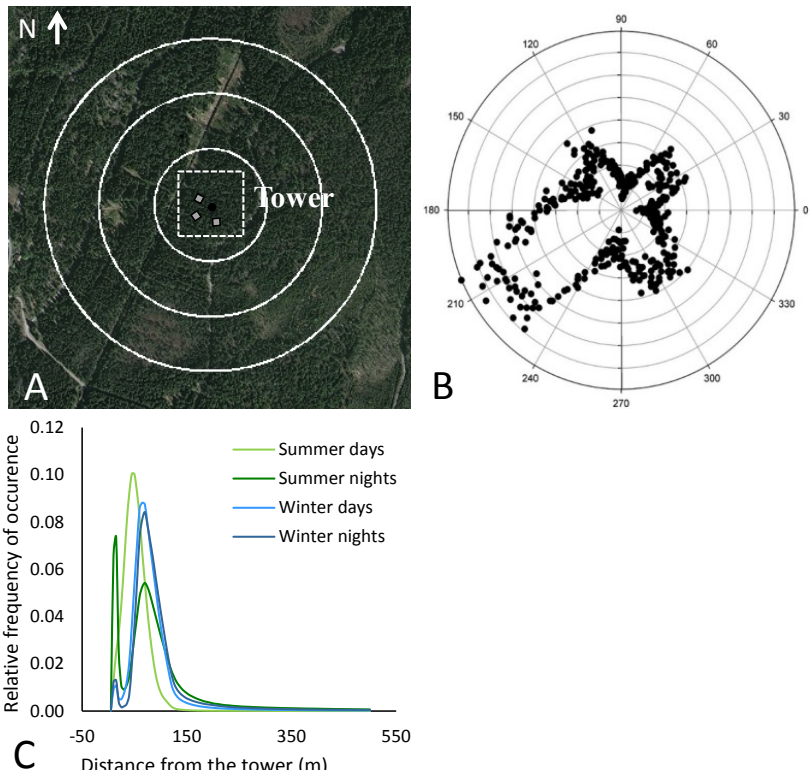

Fig. 1. (a) Position of the flux tower and of the three chamber measurement stations at the Skogaryd research catchment. The dotted line indicates the area of the $90 \times 90 \mathrm{~m}$ plot in which trees have been sampled for quantification of biomass growth. White circles indicate the distance to the tower $(100 \mathrm{~m}, 200 \mathrm{~m}$, and $300 \mathrm{~m}$, respectively). (b) Relative wind frequency for each wind direction $\left(0-360^{\circ}\right)$ and $(\mathbf{c})$ results of the footprint analysis: relative frequency of flux occurrence for the respective distance from the EC tower.

well drained so that the average water table depth in 2008 was about $38-41 \mathrm{~cm}$ in winter and $63 \mathrm{~cm}$ in summer (May to September). The soil $\mathrm{C}: \mathrm{N}$ ratio ranged between 22.7 and 26.8 in the upper $50 \mathrm{~cm}$.

The $30 \mathrm{yr}$ (1961-1990) annual mean temperature at the Vänersborg weather station, situated approximately $10 \mathrm{~km}$ east of the site, was $6.2^{\circ} \mathrm{C}$. The $30 \mathrm{yr}$ annual mean precipitation at the closest weather stations at Vänersborg and Uddevalla (12 km west of the site) was $709 \mathrm{~mm}$ and $870 \mathrm{~mm}$, respectively (www.smhi.se). The daily precipitation at the Skogaryd site in 2008 was found to correlate strongly $\left(\mathrm{R}^{2}=\right.$ 0.98 ) with the mean of the two weather stations, and we therefore assume that the long-term annual mean precipitation at the site is approximately $785 \mathrm{~mm}$.

A flux tower and three stations for soil flux measurements were established at the center of a relatively homogeneous area of the forest, extending about $200 \mathrm{~m}$ in all directions except towards the E and SE (Fig. 1a). The prevailing wind is from the SW (Fig. 1b), where the drained afforested organic site extends for more than $300 \mathrm{~m}$. The three soil flux stations are distributed within the footprint area of the EC tower. Each station consists of two plots. At each plot two measurement collars for each treatment (two control collars, two trenching collars; for details see below) were permanently installed on which the chambers for gas flux measurements were placed. 


\subsection{Measurement of abiotic variables}

To support the measurements of GHG fluxes, data on environmental parameters were collected. Air temperature was measured at the EC tower $1.5 \mathrm{~m}$ above the ground. Soil sensors for determination of soil temperature and water table depth were installed at two plots per station and were situated between the three measurement collars. Soil temperature was measured at soil depths of $0.05,0.15,0.30$ and $0.60 \mathrm{~m}$ ( $n=6$ for each soil depth, in total fours depths). Water table depth was measured using submersible pressure transducers installed in plastic tubes inserted vertically $1.5 \mathrm{~m}$ into the soil $(n=4)$. Soil temperature and water table depth were recorded every $30 \mathrm{~min}$. Details of the instruments used are given in the Appendix (Table A1).

\subsection{Determination of GHG budgets}

To determine the ecosystem budget of major GHGs for the year 2008, the net flux of $\mathrm{CO}_{2}, \mathrm{~N}_{2} \mathrm{O}$ and $\mathrm{CH}_{4}$ was determined and transformed into $\mathrm{CO}_{2}$ equivalents based on the $100 \mathrm{yr}$ global warming potential (GWP) of each gas (as given in the IPCC; Forster et al., 2007). The net flux of $\mathrm{N}_{2} \mathrm{O}$ and $\mathrm{CH}_{4}$ was determined from soil flux measurements, whereas the NEE was determined using two approaches. In the direct approach (1), NEE was determined by continuous measurement of the $\mathrm{CO}_{2}$ flux over the forest canopy using the eddy covariance (EC) technique. In the indirect approach (2), the NEE was quantified by measuring compartmental fluxes and calculating the NEE using the following equations:

$\mathrm{NEE}=\mathrm{GPP}-R=\mathrm{GPP}-R_{\mathrm{a}}-R_{\mathrm{h}}$

$\mathrm{NPP}=\mathrm{GPP}-R_{\mathrm{a}}$,

where GPP is gross primary production, NPP is net primary production, $R$ is total respiration, $R_{a}$ is autotrophic respiration and $R_{h}$ is heterotrophic respiration. Combining equations (1) and (2) gives

$\mathrm{NEE}=\mathrm{NPP}-R_{\mathrm{h}}$.

Biomass production during one year $(\Delta \mathrm{B})$ can be derived from

$\Delta B=\mathrm{NPP}-L$,

where $L$ is the total litter production. Equation (4) can be rearranged as follows:

$\mathrm{NPP}=\Delta B+L=\mathrm{AGB}_{\text {inc }}+\mathrm{BGB}_{\text {inc }}+L_{\mathrm{L}}+L_{\mathrm{R}}$,

where $\mathrm{AGB}_{\text {inc }}$ and $\mathrm{BGB}_{\text {inc }}$ are the net above- and belowground biomass increments, respectively, and $L_{L}$ and $L_{R}$ are the litter production from leaves (plus branches etc) and roots.

The heterotrophic soil respiration $R_{h}$ is typically determined by the soil chamber technique which measures the soil
$\mathrm{CO}_{2}$ efflux over time. In this study a trenching experiment was applied in order to separate between the $\mathrm{CO}_{2}$ flux from roots / mycelia and soil organic matter (SOM). As a consequence, the determination of the components of $R_{h}$, the respiration from decomposition of soil organic matter $\left(R_{S O M}\right)$ and decomposition of leaf and root litter $\left(R_{L L}, R_{L R}\right)$ become important:

$R_{\mathrm{h}}=R_{\mathrm{SOM}}+R_{\mathrm{LL}}+R_{\mathrm{LR}}$.

Combining Eqs. (3), (4a) and (5) gives

$$
\begin{aligned}
\mathrm{NEE} & =\mathrm{AGB}_{\text {inc }}+\mathrm{BGB}_{\text {inc }}+L_{\mathrm{L}}+L_{\mathrm{R}} \\
& -\left(R_{\mathrm{SOM}}+R_{\mathrm{LL}}+R_{\mathrm{LR}}\right) .
\end{aligned}
$$

In a closed canopy forest we can assume that the annual decomposition of litter from both leaves and roots equals the annual litter production by leaves and roots. For such a forest in a quasi steady state, Eq. (6) can be simplified to

$\mathrm{NEE}=\mathrm{AGB}_{\text {inc }}+\mathrm{BGB}_{\text {inc }}-R_{\mathrm{SOM}}$

so that

$R_{\mathrm{SOM}}=\mathrm{AGB}_{\text {inc }}+\mathrm{BGB}_{\mathrm{inc}}-\mathrm{NEE}$.

Equation (6a) is used in approach 2 to calculate the NEE (in the following $\mathrm{NEE}_{\text {calc }}$ ), based on determination of $\mathrm{AGB}_{\text {inc }}$, $\mathrm{BGB}_{\text {inc }}$ and $R_{\mathrm{SOM}}$, while in approach 1 , based on eddy flux measurements of the NEE (in the following $\mathrm{NEE}_{\text {meas }}$ ), $R_{\mathrm{SOM}}$ was calculated according to Eq. (6b). Details of the methods associated with each approach are given below.

\subsection{Micrometeorological measurements of NEE (approach 1)}

During 2008 continuous measurements of the $\mathrm{CO}_{2}$ flux above the canopy (maximum tree height: $25 \mathrm{~m}$ ) were carried out using the EC technique (Grelle and Lindroth, 1996). The instrumentation used was basically the same as the system described in Lindroth et al. (2008) and is listed in the Appendix (Table A1). Instrumentation was mounted on a scaffold tower. Air temperature and air humidity were measured at a height of $22 \mathrm{~m}$, while global radiation, net radiation and photosynthetically active radiation (PAR) were measured at the top of the scaffold tower at $27 \mathrm{~m}$, where the EC system was located (see Appendix). The air intake for the gas analyzer was mounted on a vertical pole which extended about $3 \mathrm{~m}$ above the top of the scaffold. The air for analysis of the $\mathrm{CO}_{2}$ concentration was drawn into the gas analyzer by means of a membrane pump at a rate of $10 \mathrm{~L} \mathrm{~min}^{-1}$ through a $5 \mathrm{~m}$ long, $4 \mathrm{~mm}$-inner-diameter polyethylene tubing. For calibration of the $\mathrm{CO}_{2}$ analyzer, an automatic 2-point system was used fortnightly, but was replaced by manual calibration later in the year. To evaluate the reliability of flux measurements, the energy balance closure was determined by taking latent 
heat, sensible heat, net radiation, the soil heat flux and storage fluxes into account (as e.g. in Wilson et al., 2002), which resulted in an energy balance closure of about $90 \%$.

Data collection and analysis were conducted in real time by the Ecoflux software (In Situ Instrument AB, Ockelbo, Sweden). In particular, flux corrections for air density fluctuations ("WPL correction"; Webb et al., 1980) were accounted for by converting the measured absorbance to dry mixing ratios by the Ecoflux software. Losses of high-frequency information due to signal attenuation in the sampling tubes were corrected by transfer functions based on tube length and diameter, air flow rate, and diffusivity of $\mathrm{CO}_{2}$ and $\mathrm{H}_{2} \mathrm{O}$, respectively. These transfer functions were then used to modify theoretical turbulence spectra based on wind speed, stability, and measurement height (Kaimal et al., 1972). From the ratio between original and modified spectra a correction factor for signal attenuation was then estimated for each $30 \mathrm{~min}$ interval.

Post-collection data analysis and gap filling followed the method described by Lindroth et al. (2008). For this, the vertical $\mathrm{CO}_{2}$ gradient was measured at seven different heights $(0.05,1.5,10,15,18,22$ and $25 \mathrm{~m}$ above the ground) using a custom-made gas exchange system (see Wallin et al., 2001 for details). In the first step, data were selected for periods when the flux measurement systems worked technically flawless and $\mathrm{CO}_{2}$ flux spikes were removed which could not be attributed to morning flushes. The $\mathrm{CO}_{2}$ storage term was calculated using data from the measurements of the vertical $\mathrm{CO}_{2}$ gradient added to the flux data to obtain the NEE. The annual average $\mathrm{CO}_{2}$ storage term constituted on average $2 \%$ of the total $\mathrm{CO}_{2}$ flux .

The gap filling was conducted as follows: daytime and nighttime data were selected according to the $\mathrm{u}^{*}>$ threshold criterion, i.e. for the values of the friction velocity at which the eddy covariance turbulence criteria were fulfilled and the atmospheric mixing was well developed. The nighttime flux, including storage, was plotted against $\mathrm{u}^{*}$ and the $\mathrm{u}^{*}$ threshold value determined visually as the point where the normalized flux started to decrease; this had a value of $0.25 \mathrm{~m} \mathrm{~s}^{-1}$.

Half-hourly data were grouped into 14-day periods and the following function fitted to the PAR data to calculate the 30 min daytime NEE flux:

$F_{c}=-\left(F_{\mathrm{csat}}+R_{d}\right) \cdot\left[1-\exp \left(\frac{-\alpha \mathrm{PAR}}{F_{\mathrm{csat}}+R_{d}}\right)\right]+R_{d}$,

where $F_{c}$ is the $30 \mathrm{~min}$ daytime NEE flux and PAR is the photosynthetically active radiation $\left(\mu \mathrm{mol} \mathrm{m}^{-2} \mathrm{~s}^{-1}\right) . F_{\mathrm{csat}}, R_{d}$ and $\alpha$ are fitting parameters.

The nighttime flux was calculated as follows:

$F_{\mathrm{cn}}=R_{0} \cdot \exp (k \cdot T)$,

where $F_{\mathrm{cn}}$ is the nighttime NEE flux $\left(\mu \mathrm{mol} \mathrm{m}{ }^{-2} \mathrm{~s}^{-1}\right), R_{0}$ and $k$ are fitting parameters and $T$ is the air temperature $(\mathrm{K})$.

If no relationship with temperature could be obtained for nighttime data, the mean value during the night for the whole period was used. For longer periods, mean diurnal halfhourly look-up tables were created using existing data based on at least 10 values per half hour (Lindroth et al., 2008). In total, $12 \%$ of the annual flux had to be gap-filled due to loss of data; a further $30 \%$ had to be gap-filled because they did not meet the $u^{*}$ criterion.

Gap-filling error estimates were produced by randomly removing $30 \%$ of measured values, filling them according to the gap-filling method used, and comparing the estimated gap-filled values with the measured values. This procedure was repeated 10 times, and the mean gap-filling error was estimated for day and night values.

The flux footprints (or flux source areas) were estimated based on the algorithms of Schmid $(1994,2002)$. For each 30 min interval, the dimensions of the elliptical source area from which $80 \%$ of the flux emanated was calculated. The corresponding surface areas were then aggregated for one year in a polar coordinate system centered by the position of the tower, resulting in three-dimensional maps displaying the frequency of flux origins for each surface element within the fetch of the tower, separately for summer and winter, day and night, respectively. This was done as follows: initially, for each of four subsets of data (i.e. summer and winter days and nights) an array representing the area surrounding the tower with a $500 \mathrm{~m}$ radius was created in polar coordinates and filled with zeros. Then, for each 30 min flux, the dimensions of the elliptical source area were calculated, and the corresponding surface area in the polar array was filled with ones. Doing so for all 30 min periods resulted in aggregations of source areas in a three-dimensional surface representation. Finally, each array was normalized to a total of $100 \%$ to make the results from the different data subsets comparable.

To simplify and clarify the presentation, data for all wind directions were then accumulated, which gives a line plot showing the relative frequency of flux occurrence as a function of distance from the tower for all data subsets (Fig. 1c). By integrating the curves over the distance, cumulative frequency distributions are obtained.

\subsection{Quantification of above- and belowground tree growth}

The annual production of aboveground and belowground biomass (including roots $\geq 1 \mathrm{~cm}$ ) (Eq. 6a, b: $A_{G B}$ inc, $\mathrm{BGB}_{\text {inc }}$ ) was determined using biomass functions developed by Marklund (1988) and modified by Minkkinen et al. (2001) for organic soils, based on diameter at breast height (dbh) and tree height. These parameters were measured for 134 trees from 16 circular sub-plots of 0.01 ha (in total $0.16 \mathrm{ha}$ ) distributed within a rectangle around the EC tower. The dbh was measured at the turn of September and October in 2007 and 2008. The initial height of the trees in 2007 was estimated based on dbh using Korf's function, which assumes an exponential relationship between dbh and tree height (Mehtätalo, 
2004). Korf's function was parameterized from measurements of dbh and tree height in 2010 on 335 trees in a $90 \times 90 \mathrm{~m}$ plot surrounding the EC tower (Fig. 1a). The 16 small sub-plots of 0.01 ha sampled for dbh were distributed uniformly within this area. The tree height increment in the 16 sub-plots was calculated from the mean annual increment in height, calculated as

$h_{\mathrm{inc}}=\frac{h_{\mathrm{tot}}-1.3}{a_{\mathrm{tot}}-a_{\mathrm{dbh}}}$,

where $h_{\text {inc }}=$ mean annual height increment $(\mathrm{m}), h_{\text {tot }}=$ total tree height $(\mathrm{m}), a_{\mathrm{tot}}=$ total age (years), and $a_{\mathrm{dbh}}=$ age at breast height (years).

The tree age was estimated from wood cores taken at breast height. The method was shown to be valid for the height increment of the trees near the tower for the last $10 \mathrm{yr}$. Based on a wood analysis, the stem C content was $49 \%$, which was used as the conversion factor for $\mathrm{C}$ content in dry biomass.

Based on an inventory of all 797 trees of the larger $90 \times 90 \mathrm{~m}$ plot (Fig. 1), the 16 sub-plots were found to have on average a $23 \%$ smaller BA than such large plot. Therefore, the biomass production was adjusted accordingly. A function established from a regression analysis of annual growth increment versus BA $\left(R^{2}=0.5\right)$ for the 16 sub-plots was used to recalculate the biomass production by applying the BA of the larger plot on this function and assuming an annual BA increase of $1.1 \mathrm{~m}^{2} \mathrm{ha}^{-1}$ (Klemedtsson et al., 2010) to adjust for changes between 2008 and the 2010 inventory.

Since fine roots $(<1 \mathrm{~cm})$ were not considered in the biomass functions by Minkkinen et al. (2001), we assumed that annual fine-root production corresponded to the increment in needle biomass that was determined from the Minkkinen et al. (2001) equations, which amounted to $3.6 \%$ of the total biomass increment. This assumption was based on publications by He et al. (2012) and White et al. (2000) showing that the ratio between the annual $\mathrm{C}$ increment of fine roots and of needles ranges between 0.6 and $3.3 \mathrm{~kg} \mathrm{C} \mathrm{kg} \mathrm{C}^{-1}$ for conifers. The majority of given values for spruce-fir forests lay between 1 and $1.5 \mathrm{~kg} \mathrm{C} \mathrm{kg} \mathrm{C}^{-1}$. Due to the wide range of values, we assigned an error estimate of $300 \%$ to the fine-root growth.

In order to receive an uncertainty estimate of tree growth, we quantified the measurement uncertainty of dbh and tree height. For this, we calculated the respective biomass in 2007 and 2008 by assuming an error of $\pm 5 \%$ in $\mathrm{dbh}$ and of $\pm 10 \%$ in tree height. The respective values for error estimates were taken from published data (McRoberts et al., 1994). The measurement uncertainty in tree growth was then determined using the respective errors of the biomass in 2007 and 2008 and applying the Gaussian error propagation scheme (Eq. 14). Furthermore, an uncertainty was assigned to the correction factor used for considering the $23 \%$ smaller BA of the 16 small plots compared to the large $90 \times 90 \mathrm{~m}$ plot. This error estimate was determined to be $50 \%$ since the variation in BA explained $50 \%$ of the variation in tree growth $\left(R^{2}=0.5\right)$.

\subsection{Soil respiration (approach 2)}

The quantification of the respiration associated with the soil organic matter (SOM) $\left(R_{\mathrm{SOM}}\right.$, Eq. $\left.6 \mathrm{~b}\right)$ was based on measurements of the soil $\mathrm{CO}_{2}$ efflux $\left(E_{\mathrm{CO}_{2}}\right)$ which were determined by the chamber method and a trenching experiment.

Details of the trenching experiment are described by Ernfors et al. (2011). Decaying roots and mycelia, cut by the trenching, added to the measured $\mathrm{CO}_{2}$ flux from $\mathrm{SOM}$ so that the measured $E_{\mathrm{CO}_{2}}$ originates from three different sources, the flux from SOM, the flux from trenched roots and mycelia, and the flux from the litter layer (litter from aboveground plant parts).

$E_{\mathrm{CO}_{2}}=R_{\mathrm{SOM}}+R_{\text {decay }}+R_{\mathrm{LL}}$

so that

$R_{\mathrm{SOM}}=E_{\mathrm{CO}_{2}}-R_{\text {decay }}-R_{\mathrm{LL}}$

where $R_{\mathrm{SOM}}$ and $R_{\mathrm{LL}}$ are the respiration from the decomposition of SOM and litter ( $\mathrm{tCha}^{-1} \mathrm{yr}^{-1}$ ) (see Eq. 5) and $R_{\text {decay }}\left(\mathrm{tCha}^{-1} \mathrm{yr}^{-1}\right)$ is the respiration from decaying roots and mycelia which were cut by trenching.

$E_{\mathrm{CO}_{2}}$ was measured using automatic transparent closed chambers at the three stations comprising two measurement plots each $(n=6)$ within the footprint area of the EC tower (Fig. 1a). Details about the chamber design and instrumentation can be found in the Appendix. Chambers were placed on permanently installed collars that covered the trenching frames. All vegetation was removed to eliminate $\mathrm{CO}_{2}$ uptake by photosynthesis. A logger system connected to the chambers prompted a measurement cycle every $20 \mathrm{~min}$. During measurement, the lid was closed and air circulated between an infrared gas analyzer and the chamber. To ensure homogenous mixing of the air, chambers were equipped with a fan. The $\mathrm{CO}_{2}$ concentration of the chamber air was measured every $30 \mathrm{~s}$ for $15 \mathrm{~min}$ before the lid was opened again and the cycle restarted. Measurements ran automatically all day for a period of three weeks at one station. Chambers were then moved to the next station where another measurements cycle of three weeks was started.

The respiration from decomposing trenched roots and mycelia, $R_{\text {decay }}$, was determined by a modified version of the method of Ngao et al. (2007) and approximated biomass decay over time (see e.g. Berg and McClaugherty, 2008). It describes an exponential decay of root biomass after trenching within the first year. Originally developed for fine roots, we extended Ngao's functions to account for coarse roots and fungal mycelia by adapting the function parameters and considering the measurement period:

$R_{\text {decay }}=(1-\alpha) \cdot m \cdot\left(1-e^{-k_{r}}\right)$, 
where $\alpha=$ microbial efficiency of decomposition; $m=$ biomass of coarse roots, fine roots and mycelia ( $\left.\mathrm{tCha}^{-1}\right)$; and $k_{r}=$ decomposition constant.

The root biomass was determined by soil coring on 5 December 2007 using a peat sampler (with a rectangular cross section measuring $8.2 \times 8.3 \mathrm{~cm}$ ). Two soil cores per plot $(n=6)$ were taken to a depth of $40 \mathrm{~cm}$. The amount of extramatrical mycorrhizal mycelia was estimated using the mesh bag technique (see Wallander et al., 2013 for a detailed description).

The respiration from the litter layer $R_{\mathrm{LL}}$ that contributes to the measured soil efflux $E_{\mathrm{CO}_{2}}$ (Eq. 10) was determined as the difference between the annual aboveground litter production from trees (total input to litter layer) and the average annual accumulation of $\mathrm{C}$ in the litter layer, assuming longterm equilibrium between inputs and outputs:

$R_{\mathrm{LL}}=L_{\mathrm{L}}-\Delta L$,

where $L_{l}=$ average annual aboveground litter production ( $\mathrm{tCha}^{-1} \mathrm{yr}^{-1}$ ), and $\Delta L=$ average annual accumulation of $\mathrm{C}$ in the litter layer $\left(\mathrm{tC} \mathrm{ha}^{-1} \mathrm{yr}^{-1}\right)$.

In order to estimate $\Delta L$, a total of 30 litter layer samples were taken across the site using a metal auger. After drying for $24 \mathrm{~h}$ at $70^{\circ} \mathrm{C}$, the annual accumulation was determined as the total mass of $\mathrm{C}$ divided by the number of years since the start of litter layer formation, i.e. since afforestation.

Aboveground plant litter production, $L_{l}$, was quantified by traps made of nylon mesh $\left(0.25 \mathrm{~m}^{2} ; n=10\right)$ that were placed evenly across the study area. Traps were emptied every sixth week, all litter fractions (needles, twigs, cones, branches) were considered and the $\mathrm{C}$ content was determined from subsamples.

\subsection{Soil $\mathrm{N}_{2} \mathrm{O}$ and $\mathrm{CH}_{4}$ fluxes}

Besides the $\mathrm{CO}_{2}$ fluxes, $\mathrm{N}_{2} \mathrm{O}$ and $\mathrm{CH}_{4}$ fluxes were quantified to determine the total GHG budget of the study site. Measurements of the $\mathrm{N}_{2} \mathrm{O}$ and $\mathrm{CH}_{4}$ fluxes were carried out once every two weeks using the closed chamber method. Measurements were taken at the control plots of the three stations around the EC tower $(n=6)$ by means of a dark chamber with a volume of $0.017 \mathrm{~m}^{3}$ that was placed on the measurement collars $\left(0.19 \mathrm{~m}^{2}\right)$ (see also Sect. 2.1). Gas samples from the chambers were taken $4,8,16$ and 32 min after lid closure and collected in vials. Gas concentration was analyzed by gas chromatography and the gas flux was determined from the slope of the linear regression line of the gas concentration plotted against time. Only $\mathrm{N}_{2} \mathrm{O}$ and $\mathrm{CH}_{4}$ fluxes from control plots (non-trenched plots) were used in the subsequent calculations. Further details on sample taking, gas analysis and flux calculation can be found in Ernfors et al. (2011).

\subsection{Handling of the flux data and calculation of annual flux rates}

Following the standard convention, we use a negative sign to indicate uptake and a positive sign to indicate gas release from the ecosystem. For $E_{\mathrm{CO}_{2}}$ a simple linear regression between hourly measured $E_{\mathrm{CO}_{2}}$ and soil temperature at $30 \mathrm{~cm}$ depth was fitted for each plot according to the function

$E_{\mathrm{CO}_{2}}=a+b \cdot t_{30}$,

where $a$ and $b$ are fitting parameters and $t_{30}$ is the soil temperature at $30 \mathrm{~cm}$ depth.

Including water table depth in the regression was tested but either did not improve goodness of fit or led to a negligible increase. Agreement between model parameters was very high for the plots of stations 1 and 2 so that the same model could be used, whereas for station 3 other parameters values had to be applied. Variation in soil temperature explained on average more than $75 \%$ of variation in $E_{\mathrm{CO}_{2}}$. Annual fluxes were calculated by summing up modeled daily values. Standard deviation of $E_{\mathrm{CO}_{2}}$ is given as the variation between stations 1, 2 and 3 .

Also for $\mathrm{N}_{2} \mathrm{O}$ fluxes a simple linear regression model to soil temperature and water table depth was tested using daily mean values. Regression was very low except for station 3 (Pearson's $r$ below 0.4). Thus, no regression model was applied to extrapolate fluxes. To calculate annual flux balances, mean daily $\mathrm{N}_{2} \mathrm{O}$ and $\mathrm{CH}_{4}$ fluxes of the missing periods were interpolated between two consecutive measurements. Annual flux balances were derived by summing up daily fluxes for each station, which were then converted to $C$ equivalents using the GWP for a $100 \mathrm{yr}$ time frame of $298\left(\mathrm{~N}_{2} \mathrm{O}\right)$ and 25 $\left(\mathrm{CH}_{4}\right)$ and the respective molar masses of $\mathrm{CO}_{2}$ and $\mathrm{C}$ (IPCC: Forster et al., 2007). To quantify the uncertainty induced by gap-filling of $\mathrm{N}_{2} \mathrm{O}$ fluxes, we calculated the gap-filling uncertainty for each gap-filled day by taking the respective standard deviation of the values used to fill the gap into account. The total flux uncertainty was quantified according to the Gauss error propagation scheme by using the standard deviation and the gap-filling uncertainty of each station (Eq. 14).

Generally, the Gauss error propagation scheme was used to calculate total uncertainty of variables consisting of several compounds (tree growth, $\mathrm{NEE}_{\text {calc }}, R_{\mathrm{SOM}}, R_{\text {res }}, \mathrm{N}_{2} \mathrm{O}$ flux) assuming that the respective components (as given e.g. in Eq. 6a and 10a) were independent:

$$
\mathrm{SDEV}_{\mathrm{tot}}=\sqrt{\mathrm{SDEV}_{\mathrm{c} 1}^{2}+\mathrm{SDEV}_{\mathrm{c} 2}^{2}+\ldots+\mathrm{SDEV}_{\mathrm{cx}}^{2}},
$$

where $\mathrm{SDEV}_{\text {tot }}=$ propagated standard deviation, and $\mathrm{SDEV}_{\mathrm{cx}}=$ standard deviation of component $1 \ldots \mathrm{x}$. 


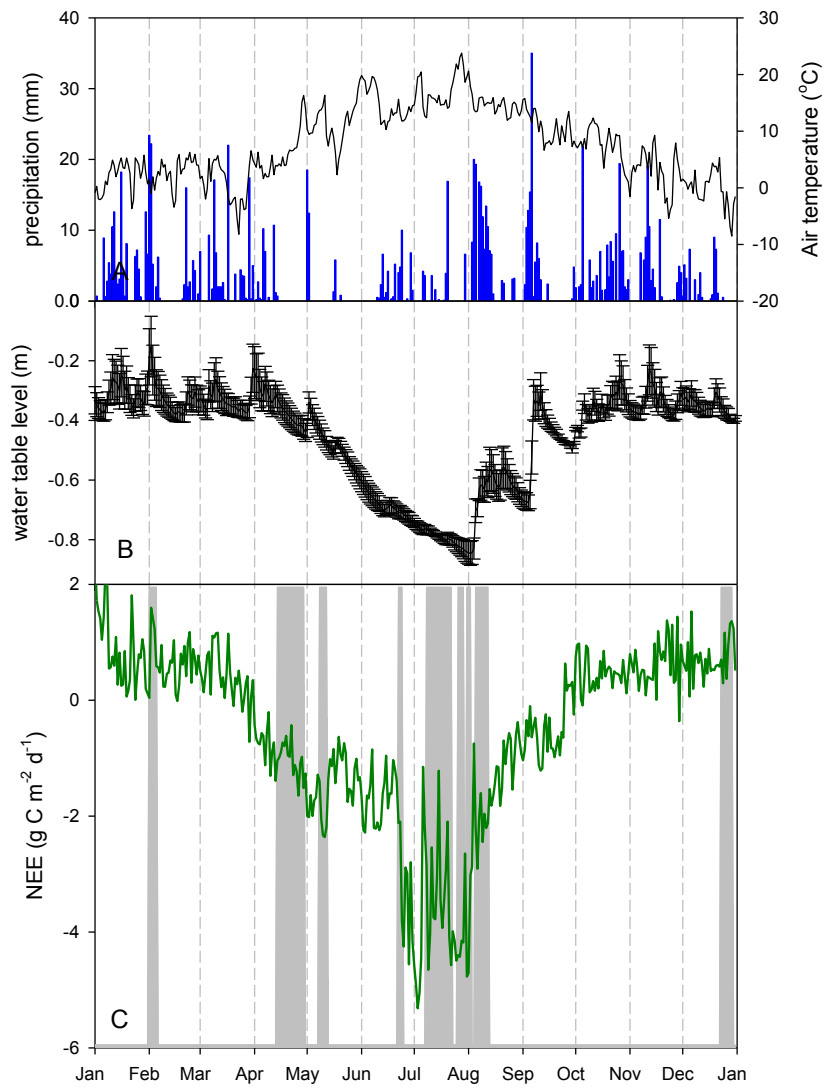

Fig. 2. (a) Daily precipitation ( $\mathrm{mm}$ ) from the Vänersborg SMHI weather station and average daily air temperature $\left({ }^{\circ} \mathrm{C}\right)$, (b) average water table depth and (c) net ecosystem exchange (NEE: $\left.\mathrm{g} \mathrm{C} \mathrm{m}^{-2} \mathrm{~d}^{-1}\right)$. The grey shadowed area indicates time periods $(>3$ days) for which data have been gap-filled.

\section{Results}

\subsection{Abiotic data}

The year 2008 was considerably warmer $\left(8.7^{\circ} \mathrm{C}\right)$ than the $30 \mathrm{yr}$ average for Vänersborg $\left(6.4^{\circ} \mathrm{C}\right)$. Records from the EC tower in Skogaryd showed that early winter (January / February) air temperature rarely fell below $0^{\circ} \mathrm{C}$ and just once in March it reached $-7^{\circ} \mathrm{C}$ (Fig. 2a). From the beginning of May, the daily mean air temperature was always well above $10^{\circ} \mathrm{C}$ apart from a short period in late May. The highest daily mean temperatures were recorded in late July $\left(23.9^{\circ} \mathrm{C}\right)$. Temperature dynamics of the second winter period 2008 (November / December) were similar to the first period (January / February) and frost only occurred occasionally. The precipitation during 2008 at the nearby weather station (Vänersborg) was above average (10 yr average: $709 \mathrm{~mm}$; 2008: $1006 \mathrm{~mm}$ ) and relatively evenly distributed over the year, except during spring (April to June) when rainfall was $30 \%$ less $(127 \mathrm{~mm})$ than the $10 \mathrm{yr}$ average for that period $(177 \mathrm{~mm})$. A persistent snow layer of up to $35 \mathrm{~cm}$ was observed for only two weeks in March (www.smhi.se).

Annual average soil temperature varied across the site and was $4.9^{\circ} \mathrm{C}, 5.8^{\circ} \mathrm{C}$ and $6.9^{\circ} \mathrm{C}$ for station 1 , station 2 , and station 3, respectively. Annual average water table depth for the whole site was $0.45 \mathrm{~m}$ with only small variations between stations (Fig. 2b).

\subsection{NEE as determined by micrometeorological methods}

The accumulated NEE in 2008 was $-2.0 \pm 0.3 \mathrm{tC} \mathrm{ha}^{-1} \mathrm{yr}^{-1}$ and varied strongly between seasons. During the first winter period NEE ranged between 0 and $2.3 \mathrm{~g} \mathrm{C} \mathrm{m}^{-2} \mathrm{~d}^{-1}$. The NEE was positive from 1 January until 29 March, when the ecosystem switched to being a C sink (Fig. 2c). NEE decreased rapidly until mid-May but remained then constant until the end of June. The highest net $\mathrm{CO}_{2}$ uptake was reported in July $\left(-5.3 \mathrm{~g} \mathrm{C} \mathrm{m}^{-2} \mathrm{~d}^{-1}\right)$. In late September, the site returned to acting as a $\mathrm{C}$ source, with emissions ranging between 0 and $1.5 \mathrm{~g} \mathrm{C} \mathrm{m}^{-2} \mathrm{~d}^{-1}$. In November and December the $30 \mathrm{~min}$ averaged NEE values showed a strong negative correlation to air temperature $\left(R^{2}=-0.78\right)$.

The average gap-filling error was estimated to be $6 \%$ and $14 \%$ for daytime and nighttime values, respectively, corresponding to an uncertainty of $\pm 13 \mathrm{~g} \mathrm{C} \mathrm{m}^{-2}$ for all gap-filled data and an uncertainty of $\pm 6.5 \%$ of the total annual flux. The gap-filling procedure showed good agreement during the growing season although the nighttime fluxes were underestimated. During January and February 2008 the nighttime fluxes were heavily overestimated by the gap-filling model, but this did not contribute considerably to the total annual flux. The reason behind this could not be clarified completely but is probably due to longer data gaps during these calm and stable winter nights and a worse fit of the gap-filling model.

During days, the source distance distribution around the tower peaked at $50-100 \mathrm{~m}$, and the $90 \%$ limit was within $175 \mathrm{~m}$ during both days and nights (Fig. 1c). During nights, the source area occasionally moved further away, but never more than $250 \mathrm{~m}$. This, in relation to homogeneous fetch conditions, means that the measured fluxes were certainly dominated by the surrounding forest stand (Fig. 1b).

The flux footprint analysis showed that flux frequencies are bimodally distributed (Fig. 1c) with a secondary maximum closer to the tower which is most pronounced during summer nights. This maximum corresponds to periods of nocturnal instability, which have been observed in an earlier study by flux measurements at different heights that revealed the growth of a stable layer from below (Grelle et al., 1997).

\subsection{Biomass production}

Standing biomass (including roots $\geq 1 \mathrm{~cm}$ ) - calculated using the Minkkinen et al. (2001) equations - amounted to 259 and $273 \mathrm{tdm} \mathrm{ha}^{-1}$ in 2007 and 2008 , respectively. 
The coarse-root biomass $(>1 \mathrm{~cm})$ was estimated to be $45.7 \mathrm{t} \mathrm{dm} \mathrm{ha}^{-1}$ (2007) and $47.9 \mathrm{tdm} \mathrm{ha}^{-1}$ (2008). The resulting tree growth in 2008 corrected according to the BA factor and including fine-root growth was $8.3 \pm 3.9 \mathrm{tC} \mathrm{ha}^{-1} \mathrm{yr}^{-1}$.

\subsection{NEE as determined by compartment fluxes}

Applying Eq. (6a) to the measured data of soil processes and biomass production resulted in a NEE of $-0.2 \pm 4.4 \mathrm{tC} \mathrm{ha}^{-1} \mathrm{yr}^{-1}$ (Table 4). The measured soil $\mathrm{CO}_{2}$ efflux, $E_{\mathrm{CO}_{2}}$, in 2008 was $13.0 \pm 1.7 \mathrm{tCha}^{-1} \mathrm{yr}^{-1}$. Fluxes were highest from station $3\left(14.9 \mathrm{tCha}^{-1} \mathrm{yr}^{-1}\right)$, whereas fluxes from the other stations were 12.6 (station 1) and 11.5 (station 2) $\mathrm{tCha}^{-1} \mathrm{yr}^{-1}$. The reason behind the variation is likely the higher average soil temperature at station 3 since it could be shown by the regression analysis that measured heterotrophic soil efflux $E_{\mathrm{CO}_{2}}$ responded strongly to soil temperature, whereas the inclusion of water table depth only slightly increased the fit of the regression model. The low response to water table depth was also observed by Ojanen et al. (2010) and Mäkiranta et al. (2008) and is likely to be caused by the generally high drainage level of below $30 \mathrm{~cm}$. Fresh litter with the highest potential for decomposition is deposited on the soil surface so that the water table would need to rise considerably to have an effect on the decomposition.

The respiration from decaying roots in the trenched plots amounted to $1.5 \pm 0.3 \mathrm{tC} \mathrm{ha}^{-1} \mathrm{yr}^{-1}$ for fine roots and $0.7 \pm 0.5 \mathrm{tCha}^{-1} \mathrm{yr}^{-1}$ for coarse roots, resulting in a total $R_{\text {decay }}$ of $2.2 \pm 0.6 \mathrm{tCha}^{-1} \mathrm{yr}^{-1}$ (Table 1). The biomass of mycorrhizal fungal mycelia was very small, which is why their impact on the $\mathrm{CO}_{2}$ flux was ignored. The average annual litter fall was $2.9 \pm 1.1 \mathrm{tC} \mathrm{ha}^{-1} \mathrm{yr}^{-1}$ and the annual litter accumulation $0.2 \pm 0.1 \mathrm{tC} \mathrm{ha}^{-1} \mathrm{yr}^{-1}$, which sums to an annual net respiration from decomposing litter of $2.7 \pm 1.0 \mathrm{tCha}^{-1} \mathrm{yr}^{-1}$. As a result, the respiration from SOM, $R_{\mathrm{SOM}}$, was $8.1 \pm 2.1 \mathrm{tC} \mathrm{ha}^{-1} \mathrm{yr}^{-1}$.

\section{5 $\quad \mathrm{N}_{2} \mathrm{O}$ and $\mathrm{CH}_{4}$ fluxes}

The measured $\mathrm{CH}_{4}$ flux was, on average, $-4.4 \pm 2.3 \mathrm{~kg} \mathrm{CH}_{4} \mathrm{ha}^{-1} \mathrm{yr}^{-1}$, i.e. $\mathrm{CH}_{4}$ was taken up by the soil. In contrast, $\mathrm{N}_{2} \mathrm{O}$ fluxes constituted a major greenhouse gas source, averaging $11.1 \pm 9.3 \mathrm{~kg} \mathrm{~N}_{2} \mathrm{O} \mathrm{ha}^{-1} \mathrm{yr}^{-1}$ (see also Ernfors et al., 2011) which corresponds to $0.9 \pm 0.8 \mathrm{tC}_{\mathrm{eq}} \mathrm{ha}^{-1} \mathrm{yr}^{-1}$ (Table 2). The response of $\mathrm{N}_{2} \mathrm{O}$ fluxes to soil temperature and water table depth was low for all plots expect one $\left(\mathrm{R}^{2}<0.4\right)$, so that no regression model was applied to extrapolate fluxes.

\subsection{Two approaches to determining NEE and overall GHG budget}

The measurements conducted in this study allow for a comparison of the two different approaches to quantify the NEE of an afforested organic soil: direct measurement by mi-

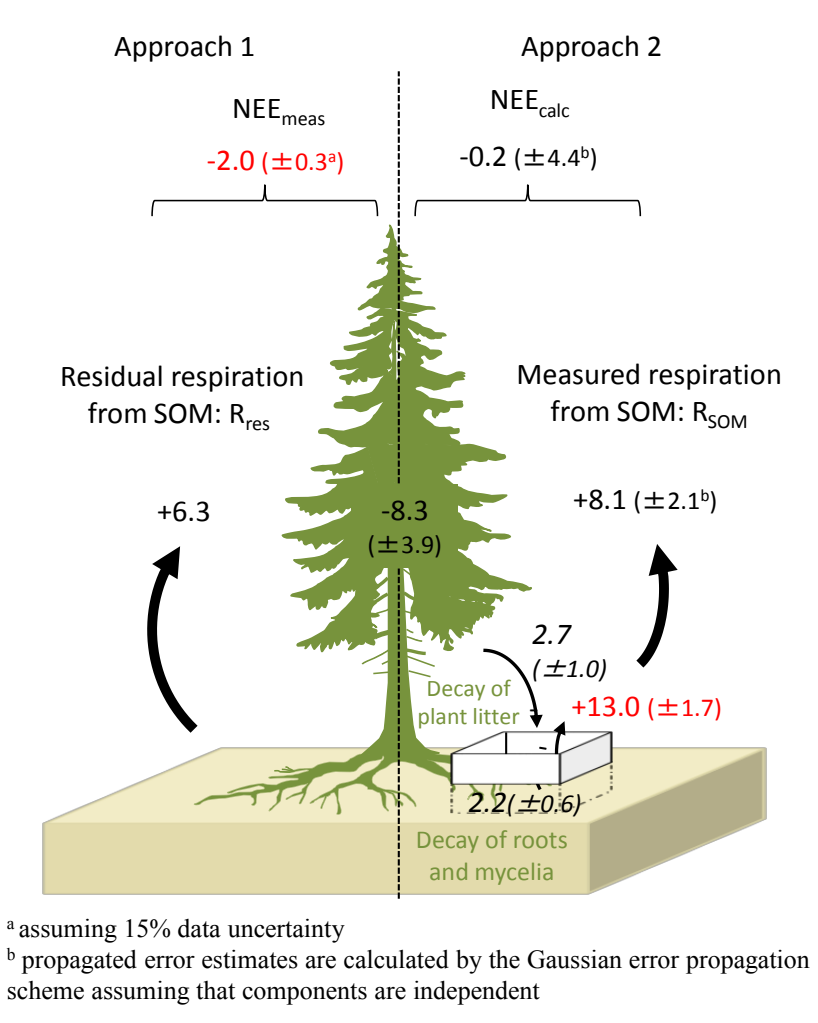

Fig. 3. Net ecosystem $C$ exchange at the Skogaryd research catchment as determined by two approaches. In approach 1 (left), NEE is measured directly by the EC technique and the respiration from SOM $\left(R_{\text {res }}\right)$ is determined as the residual flux of the measured $\mathrm{NEE}_{\text {meas }}$ and the calculated tree growth. In approach 2 (right), the $\mathrm{NEE}$ is calculated as the residual flux $\mathrm{NEE}_{\text {calc }}$ based on the quantification of the respiration from SOM ( $R_{\mathrm{SOM}}$, see text for details). Measured gross fluxes are given as red numbers, calculated gross fluxes as black numbers, calculated net effluxes as italics. All fluxes in $\mathrm{tCha}^{-1} \mathrm{yr}^{-1}$.

crometeorological methods and indirect quantification via soil respiration and $\mathrm{C}$ accumulation in tree biomass. The two approaches are illustrated in Fig. 3. The direct approach identified the site as a $\mathrm{C}$ sink of $-2.0 \pm 0.3 \mathrm{tCha}^{-1} \mathrm{yr}^{-1}$ $\left(\mathrm{NEE}_{\text {meas }}\right)$. Since the understorey vegetation is sparse and therefore likely to exhibit negligible fluxes, the difference between the annual tree growth and $\mathrm{NEE}_{\text {meas }}$ gives an estimate of the respiration from $\operatorname{SOM}\left(R_{\mathrm{res}}\right)$ of $6.3 \mathrm{tC} \mathrm{ha}^{-1} \mathrm{yr}^{-1}$. In the second approach, the NEE is estimated indirectly $\left(\mathrm{NEE}_{\text {calc }}\right)$ based on the difference between annual tree growth and measured soil efflux, corrected for the $\mathrm{CO}_{2}$ efflux from decaying roots and litter. The respiration from SOM ( $R_{\mathrm{SOM}}$ ) was $8.1 \pm 2.1 \mathrm{tCha}^{-1} \mathrm{yr}^{-1}$ so that the $\mathrm{NEE}_{\text {calc }}$ became $-0.2 \pm 4.4 \mathrm{tC} \mathrm{ha}^{-1} \mathrm{yr}^{-1}$ (Fig. 3).

When NEE was combined with fluxes of $\mathrm{CH}_{4}$ and $\mathrm{N}_{2} \mathrm{O}$ (see above) the total flux balance of GHGs using approach 1 and 2 became $-1.2 \pm 0.8 \mathrm{tC}_{\mathrm{eq}} \mathrm{ha}^{-1} \mathrm{yr}^{-1}$ and $0.6 \pm 4.5 \mathrm{tC}_{\mathrm{eq}} \mathrm{ha}^{-1} \mathrm{yr}^{-1}$, respectively (Table 4). Thus, 
Table 1. Biomass in autumn $2007\left(\mathrm{tCha}^{-1}\right)$ and respective parameter values of fine roots, coarse roots, and fungal mycelia used for the calculation of the respiration from decaying roots and mycelia $\left(R_{\text {decay }}\right)$. If not stated otherwise, parameter values were used as given in Ngao et al. (2007). $\alpha=$ microbial efficiency, $k_{r}=$ decomposition constant.

\begin{tabular}{|c|c|c|c|c|c|}
\hline & $\begin{array}{c}\text { Biomass } \\
\left(\mathrm{tCha}^{-1}\right)\end{array}$ & $\begin{array}{l}\text { Determined } \\
\text { by method }\end{array}$ & $\alpha$ & $\begin{array}{c}k_{r} \\
\left(\mathrm{yr}^{-1}\right)\end{array}$ & $\begin{array}{c}\text { Calculated flux } \\
( \pm \text { stand. dev. }) \\
\quad\left(\mathrm{tCha}^{-1}\right)\end{array}$ \\
\hline $\begin{array}{l}\text { Fine roots } \\
(<1 \mathrm{~cm})\end{array}$ & 6.2 & Measured $^{\mathrm{a}}$ & $0.4^{\mathrm{b}}$ & 0.5 & $1.5(0.4)^{\mathrm{c}}$ \\
\hline Coarse roots & 23.4 & $\begin{array}{l}\text { Minkkinnen } \\
\text { et al. (2001) }\end{array}$ & 0.3 & $0.045^{\mathrm{d}}$ & $0.7(0.5)^{\mathrm{c}}$ \\
\hline $\begin{array}{l}\text { Fungal } \\
\text { mycelia }\end{array}$ & 0.023 & Measured $^{\mathrm{a}}$ & $0.4^{\mathrm{b}}$ & 0.5 & $<0.00$ \\
\hline
\end{tabular}

Table 2. $\mathrm{CH}_{4}\left(\mathrm{~kg} \mathrm{CH}_{4} \mathrm{ha}^{-1} \mathrm{yr}^{-1}\right)$ and $\mathrm{N}_{2} \mathrm{O}\left(\mathrm{kg} \mathrm{N}_{2} \mathrm{Oha}^{-1} \mathrm{yr}^{-1}\right)$ fluxes and the corresponding flux in $\mathrm{C}$ equivalents $\left(\mathrm{t} \mathrm{C}_{\mathrm{eq}}\right.$ ha $\left.{ }^{-1} \mathrm{yr}^{-1}\right)$ ( \pm uncertainty) at the Skogaryd research catchment for 2008. C equivalents were calculated based on the $100 \mathrm{yr}$ global warming potential of each gas (IPCC: Forster et al., 2007)

\begin{tabular}{|c|c|c|c|c|c|}
\hline & Station 1 & Station 2 & Station 3 & Mean flux & $\mathrm{C}$ equivalent $\left(\mathrm{t}_{\mathrm{eq}} \mathrm{ha}^{-1} \mathrm{yr}^{-1}\right)$ \\
\hline $\mathrm{N}_{2} \mathrm{O}$ flux $\left(\mathrm{kg} \mathrm{N}_{2} \mathrm{O} \mathrm{ha}^{-1} \mathrm{yr}^{-1}\right)$ & 3.5 & 11.1 & 18.7 & $11.1 \pm 9.3$ & $0.9 \pm 0.8$ \\
\hline $\mathrm{CH}_{4}$ flux $\left(\mathrm{kg} \mathrm{CH}_{4} \mathrm{ha}^{-1} \mathrm{yr}^{-1}\right)$ & -5.8 & -1.7 & -5.6 & $-4.4 \pm 2.3$ & $-0.1 \pm 0.0$ \\
\hline
\end{tabular}

approach 1 indicated the site to be a small net sink while approach 2 indicated a small net source.

\section{Discussion}

\subsection{Quantification of the NEE and compartmental fluxes}

The two approaches used to quantify the NEE differed by almost $2 \mathrm{tCha}^{-1} \mathrm{yr}^{-1}$, but the high uncertainty associated with approach 2 does not allow to conclude that both results are significantly different from each other. Considering the uncertainty range, $\mathrm{NEE}_{\text {calc }}$ could be positive or negative whereas $\mathrm{NEE}_{\text {meas }}$ constitutes a clear $\mathrm{C}$ sink. It must be kept in mind that the propagated error of $\mathrm{NEE}_{\text {calc }}$ was determined according to the Gauss error propagation scheme (Eq. 14). Due to the nature of this calculation, a low standard error of the components of the equation will yield a relatively high propagated error estimate. Nevertheless, it must be emphasized that approach 2 is associated with a much higher uncertainty level and is consequently less appropriate to gain precise estimates of the ecosystem $\mathrm{C}$ balance.

Comparison of the NEE with that of other similar sites is hampered because of the scarcity of year-round measurements in the literature. To our knowledge, there are no com- parable studies from Sweden, but in Finland studies at similar site conditions (depth of the peat, vegetation, drainage level) and climate conditions (situated in the hemiboreal to boreal region) have been conducted. Lohila et al. (2011) found a $\mathrm{NEE}$ of $-2.4 \mathrm{tC} \mathrm{ha}^{-1} \mathrm{yr}^{-1}$ for a pine forest on a drained organic soil (Table 3). However, that site had no agricultural history and the soil had a much lower soil $\mathrm{N}$ content $(\mathrm{C}: \mathrm{N}$ of 34 to 41) leading to lower $\mathrm{C}$ accumulation in trees and, in contrast to the site of the present study, a net accumulation of $\mathrm{C}$ in the soil due to limited peat decomposition. A young pine forest on a former agricultural land was found to be a restricted C source of $0.14 \mathrm{t} \mathrm{C} \mathrm{ha}^{-1} \mathrm{yr}^{-1}$ (Lohila et al., 2007). In the latter study, the organic soil lost large amounts of $\mathrm{C}$ that could not be completely compensated for by the $\mathrm{C}$ accumulation in the trees. However, the forest was only $30 \mathrm{yr}$ old with a $\mathrm{C}$ accumulation of $2.4 \mathrm{t} \mathrm{C} \mathrm{ha}^{-1} \mathrm{yr}^{-1}$ which did not include fine roots. Furthermore, the $\mathrm{C}$ budget at that site could not be quantified completely, and Lohila et al. (2007) stated that the site possibly could be a $\mathrm{C}$ sink if $\mathrm{C}$ accumulation in ground vegetation and belowground litter production were included. Other studies on the NEE of forests on organic soils have been undertaken by Dunn et al. (2007) and Flanagan and Syed (2011), but the comparability is limited because site conditions differ considerably from our site with respect to vegetation (natural, not afforested), management history (no drainage) and the much higher forest age of $160 \mathrm{yr}$. Overall, 
Table 3. Annual tree growth, NEE and respiration from SOM determined at comparable organic sites. If not stated otherwise, units are $\mathrm{tCha}^{-1} \mathrm{yr}^{-1}$.

\begin{tabular}{|c|c|c|c|c|c|c|c|c|}
\hline Reference & Site & Period & Species & $\begin{array}{l}\text { Forest } \\
\text { age }(\mathrm{yr})\end{array}$ & $\begin{array}{c}\text { Stem } \\
\text { density } \\
\left(\text { trees ha }^{-1}\right)\end{array}$ & $\begin{array}{l}\text { Tree } \\
\text { growth }\end{array}$ & NEE & $\begin{array}{c}\text { SOM } \\
\text { respiration }\end{array}$ \\
\hline $\begin{array}{l}\text { von Arnold } \\
\text { et al. (2005) }\end{array}$ & $\begin{array}{l}\text { Sweden, } \\
\text { Asa }\end{array}$ & $2000-02$ & $\begin{array}{l}\text { Norway } \\
\text { spruce }\end{array}$ & 90 & 750 & 3.5 & & \\
\hline $\begin{array}{l}\text { Lohila } \\
\text { et al. (2011) }\end{array}$ & $\begin{array}{l}\text { Finland, } \\
\text { Kalevansuo }\end{array}$ & 2005 & $\begin{array}{l}\text { Natural pine } \\
\text { and birch }\end{array}$ & & 835 & 1.6 & -2.4 & \\
\hline $\begin{array}{l}\text { Lohila } \\
\text { et al. (2007) }\end{array}$ & $\begin{array}{l}\text { Finland, } \\
\text { Alkkia }\end{array}$ & 2003 & Scots pine & 32 & 977 & 2.4 & 0.14 & \\
\hline $\begin{array}{l}\text { Mäkiranta } \\
\text { et al. (2007) }\end{array}$ & $\begin{array}{l}\text { Finland, } \\
\text { Alkkia }\end{array}$ & 2003-04 & Scots pine & 32 & & & & 4.8 \\
\hline $\begin{array}{l}\text { Mäkiranta } \\
\text { et al. (2010) }\end{array}$ & $\begin{array}{l}\text { Finland, } \\
\text { Padasjoki }\end{array}$ & 2001-04 & Scots pine & 60 & & 1.9 & & 4.1 \\
\hline $\begin{array}{l}\text { Ojanen } \\
\text { et al. (2010) }\end{array}$ & $\begin{array}{l}\text { Finland, } \\
68 \text { sites }\end{array}$ & $2007-08$ & Coniferous & & & & & 1.5 to 6.7 \\
\hline This study & $\begin{array}{l}\text { Sweden, } \\
\text { Skogaryd }\end{array}$ & 2008 & $\begin{array}{l}\text { Spruce } \\
\text { dominated }\end{array}$ & 60 & 985 & 8.2 & $0.0^{\mathrm{b}}$ to $-2.0^{\mathrm{a}}$ & $6.2^{\mathrm{a}}$ to $8.2^{\mathrm{b}}$ \\
\hline
\end{tabular}

a Approach 1: EC.

${ }^{\mathrm{b}}$ Approach 2: chambers.

the $\mathrm{NEE}_{\text {meas }}$ from our study appears to be reasonable compared to values reported from Finland, whereas the $\mathrm{NEE}_{\text {calc }}$ seems comparatively high considering the high level of $\mathrm{C}$ accumulation in trees.

The estimated tree growth of $8.3 \pm 3.9 \mathrm{tCha}^{-1} \mathrm{yr}^{-1}$ is higher than reported values for similar ecosystems in Sweden and Finland (Table 3). The study site at Skogaryd is very nutrient-rich due to its former use for agricultural crops. This, together with the fact that the site is well drained and located in the hemiboreal zone with a more favorable climate for tree growth, allows for a higher productivity compared to Finnish sites (Lohila et al., 2007, 2011; see Table 3). The lower annual tree growth observed on the nutrient-rich organic soil reported by von Arnold et al. (2005b) can probably be explained by tree age. The trees at their site were $90 \mathrm{yr}$ old, and were already older than the age associated with maximum biomass production (Gower et al., 1996; Black and Gallagher, 2010).

The high C uptake of the trees is to a large extent compensated by the respiration from SOM. However, when determined by the chamber technique ( $R_{\mathrm{SOM}}$, approach 2$)$ respiration was about $30 \%$ higher compared to the residual flux $R_{\text {res }}$ of approach $1 . R_{\mathrm{SOM}}$ is higher than reported values from organic sites across Finland ( 1.5 to $6.7 \mathrm{tC} \mathrm{ha}^{-1} \mathrm{yr}^{-1}$; see Table 3) and also higher than fluxes from nutrient-rich agricultural sites (4.5 to $5.5 \mathrm{tC} \mathrm{ha}^{-1} \mathrm{yr}^{-1}$, Kasimir Klemedtsson et al., 1997), whereas $R_{\text {res }}$ ranges at the upper end of reported values. Generally, the heterotrophic soil $\mathrm{CO}_{2}$ efflux $R_{h}$ is one of the largest fluxes in ecosystems (Hanson et al., 2000; Schlesinger et al., 2000), which implies that even small uncertainties in the components of this flux (see Eq. 5) can equate to the size of the total net $\mathrm{C}$ flux (Ojanen et al., 2012). The discrepancy between approaches points to some uncertainties associated with the methods applied, which will be discussed in detail in Sect. 4.5.

\subsection{Potential losses due to discharge}

The export of $\mathrm{C}$ from the soil to streams and ditches is a factor with potential impact on the ecosystem $\mathrm{C}$ budget (Nilsson et al., 2008) that was not quantified in the present study. For afforested organic soils, total organic C (TOC) export ranges between 58 and $115 \mathrm{~kg} \mathrm{Cha}^{-1} \mathrm{yr}^{-1}$ and depends on a variety of factors including the organic matter content, discharge during the spring melting period as well as the magnitude of winter precipitation (Laudon et al., 2004; Köhler et al., 2008; Haei et al., 2010; Rantakari et al., 2010; Dyson et al., 2011). Due to the high $\mathrm{C}$ content and the high winter precipitation in 2008 the TOC export in Skogaryd was probably higher than that reported in studies by Köhler et al. (2008) and Dyson et al. (2011), where soils had a lower $\mathrm{C}$ content. However, there was no consistent snow layer in Skogaryd in 2008, so that the impact of the spring melting period was probably negligible. Total inorganic C (TIC) export reported in the literature seems to be of minor importance $\left(<30 \mathrm{~kg} \mathrm{Cha}^{-1} \mathrm{yr}^{-1}\right.$; Öquist et al., 2009; Rantakari et al., 2010; Wallin et al., 2010; Dyson et al., 2011). Overall, with reported maxima of 30 and $115 \mathrm{~kg} \mathrm{Cha}^{-1} \mathrm{yr}^{-1}$, the contribution of discharge $\mathrm{C}$ losses to the total $\mathrm{C}$ budget at Skogaryd is probably low as literature 
values constitute less than $2 \%$ of the annual tree growth and the respiration from SOM

\section{3 $\mathrm{N}_{2} \mathrm{O}$ and $\mathrm{CH}_{4}$ fluxes}

The measured $\mathrm{CH}_{4}$ flux was very low and always negative; i.e. $\mathrm{CH}_{4}$ was taken up by the soil. These results are similar to values previously reported for drained organic soils in Sweden, Finland, the UK and Germany for different types of coniferous forests $\left(-0.18\right.$ and $-2.0 \mathrm{~kg} \mathrm{Cha}^{-1} \mathrm{yr}^{-1}$; e.g. Kasimir Klemedtsson et al., 1997; Minkkinen et al., 2002; Huttunen et al., 2003; Maljanen et al., 2003a; von Arnold et al., 2005b; Yamulki et al., 2013). Due to the low magnitude of the flux, the contribution to the GHG budget is negligible (Table 4). The source potential at the site might be underestimated due to possible $\mathrm{CH}_{4}$ emissions from ditches, which were not considered in this study. Previous studies have shown that, depending on the water movement and water temperature, $\mathrm{CH}_{4}$ emissions can be 10 times as high as from neighboring soil (von Arnold et al., 2005b; Minkkinen and Laine, 2006).

In contrast to $\mathrm{CH}_{4}$, significant $\mathrm{N}_{2} \mathrm{O}$ fluxes of $11.1 \pm 9.3 \mathrm{~kg} \mathrm{~N}_{2} \mathrm{O} \mathrm{ha}^{-1} \mathrm{yr}^{-1}$ were observed, which are higher than reported values $\left(0.4-8.1 \mathrm{~kg} \mathrm{~N}_{2} \mathrm{O} \mathrm{ha}^{-1} \mathrm{yr}^{-1}\right.$ : Maljanen et al., 2003b; von Arnold et al., 2005b; Alm et al., 2007; Yamulki et al., 2013). Comparing the 2008 flux estimate to the preceding and following year (2007: $9.7 \pm 8.9 \mathrm{~kg} \mathrm{~N}_{2} \mathrm{O} \mathrm{ha}^{-1} \mathrm{yr}^{-1} ; \quad 2009$ : $5.1 \pm 2.6 \mathrm{~kg} \mathrm{~N}_{2} \mathrm{O} \mathrm{ha}^{-1} \mathrm{yr}^{-1}$ ) shows that fluxes in 2008 were highest and about $1.4 \mathrm{~kg} \mathrm{~N}_{2} \mathrm{O} \mathrm{ha}^{-1} \mathrm{yr}^{-1}$ higher compared to 2007. In 2008, also air temperature and precipitation were above average, so that especially in August and September warm and wet conditions probably stimulated $\mathrm{N}_{2} \mathrm{O}$ emissions (Fig. 2a). Therefore, fluxes in 2008 were exceptional but reasonable with regard to climatic conditions. The generally high $\mathrm{N}_{2} \mathrm{O}$ emissions from the present site can be explained by the relatively low soil $\mathrm{C}: \mathrm{N}$ ratio of 22 to 23 . Klemedtsson et al. (2005) found that $\mathrm{N}_{2} \mathrm{O}$ emissions rapidly increase with reductions in the soil $\mathrm{C}: \mathrm{N}$ below a threshold ratio of 25. Although water table has been identified as one of the determining factors for $\mathrm{N}_{2} \mathrm{O}$ emissions, especially for oligotrophic soils (Martikainen et al., 1993), the response of $\mathrm{N}_{2} \mathrm{O}$ fluxes to the water table depth in our study was only low as tested by a regression model. The same applies to the soil temperature. One reason behind this is probably the only-fortnightly measurement frequency. Furthermore $\mathrm{N}_{2} \mathrm{O}$ emissions seem to respond strongly to intermediate soil moisture conditions (Jungkunst and Fiedler, 2007), which means that changing water table depths creating frequent changes between drier and wetter conditions could stimulate $\mathrm{N}_{2} \mathrm{O}$ production so that no clear correlation can be found.

Our numbers corroborate the $\mathrm{N}_{2} \mathrm{O}$ effluxes summarized in a review by Alm et al. (2007), where an efflux of up to $10 \mathrm{~kg} \mathrm{~N}_{2} \mathrm{O} \mathrm{ha}^{-1} \mathrm{yr}^{-1}$ was reported for nutrient-rich welldrained pine fens and spruce mires. Together, these results in- dicate that the value of the default emission factor in the 2006 IPCC Guidelines for nutrient-rich drained organic forest soils is probably too low: $0.9(0.25-3.7) \mathrm{kg} \mathrm{N}_{2} \mathrm{O} \mathrm{ha}^{-1} \mathrm{yr}^{-1}$.

\subsection{Overall GHG budget}

Considering all GHG fluxes, the calculated GHG budget is negative $\left(-1.2 \pm 0.8 \mathrm{tCha}^{-1} \mathrm{yr}^{-1}\right)$ when determined according to approach 1 or positive when determined by approach $2\left(0.6 \pm 4.5 \mathrm{tCha}^{-1} \mathrm{yr}^{-1}\right.$, Table 4). However, the much higher uncertainty range associated with approach 2 allows the GHG balance to cross zero; i.e. the site could be a net GHG source or a sink whereas the site is a clear sink according to approach 1 .

Our results contrast with the findings of Ojanen et al. (2012), who compared the EC technique and the chamber technique and balance calculations to determine soil $\mathrm{C}$ balance. They found only marginal differences between the soil effluxes using the two different methods. However, they pointed out that the chamber estimation depends largely on assumed turnover rates of fine roots to calculate belowground litter production. Using the lowest values of their given range, the $\mathrm{EC}$ and the chamber approach by Ojanen et al. (2012) differed by almost $2 \mathrm{tC} \mathrm{ha}^{-1} \mathrm{yr}^{-1}$. Furthermore they did not, to our knowledge, correct for the decay of roots and mycelia in trenched measurement collars. These factors can lead to either an underestimation (e.g. due to missing mycelia litter input) or an overestimation of the soil $\mathrm{C}$ losses (e.g. due to an overestimation of the measured heterotrophic flux) so that it is difficult to estimate the net effect.

\subsection{Uncertainty in the terms of the $C$ budget}

\subsubsection{Biomass}

Both approaches used in this study to quantify the NEE of a nutrient-rich afforested organic site rely on correct estimates of tree growth which are based on biomass equations. Uncertainties involved in the application of such equations can in principle be distinguished between model uncertainty, sampling uncertainty and measurement uncertainty (Melson et al., 2011; Chave et al., 2004; Jenkins et al., 2003). Model uncertainty is caused by an inappropriate set of allometric functions and parameters to describe the forest stand and its species composition accurately. However, in our study, the application of the Minkkinen et al. (2001) equations is the most appropriate model available. First, the equations were specifically developed for species common in Swedish forests, i.e. for the species studied (Norway spruce, Scots pine and silver birch), site fertility and site climate. Second, the Minkkinen et al. (2001) equations account for the effect of the soil type (organic) on root growth, which has been shown to be higher in organic than in mineral soils (Laiho and Finer, 1996). Sampling uncertainty is related to the size of the study plot. In this study the systematic selection of 16 
Table 4. Total GHG budget at the Skogaryd research catchment, 1229 presented as $\mathrm{C}$ equivalents determined by the measured $\mathrm{N}_{2} \mathrm{O}$ and $\mathrm{CH}_{4}$ flux and two different approaches to determining the NEE. All units are $\mathrm{tC}_{\mathrm{eq}} \mathrm{ha}^{-1} \mathrm{yr}^{-1}$.

\begin{tabular}{|c|c|c|c|c|c|}
\hline & & \multicolumn{2}{|c|}{$\begin{array}{c}\text { Approach } 1 \\
(\mathrm{GHG} \text { flux } \pm \text { stdev })\end{array}$} & \multicolumn{2}{|c|}{$\begin{array}{c}\text { Approach } 2 \\
(\mathrm{GHG} \text { flux } \pm \text { stdev })\end{array}$} \\
\hline \multicolumn{6}{|l|}{ Plant $\mathrm{CO}_{2}$ flux } \\
\hline Tree growth & $\Delta B$ & -8.3 & 3.9 & -8.3 & 3.9 \\
\hline \multicolumn{6}{|l|}{ Soil $\mathrm{CO}_{2}$ fluxes } \\
\hline Measured soil flux & $E_{\mathrm{CO}_{2}}$ & & & 13.0 & 1.7 \\
\hline Respiration from litter layer & $R_{\mathrm{LL}}$ & & & 2.7 & 1.0 \\
\hline Decay from roots & $R_{\text {decay }}$ & & & 2.2 & 0.6 \\
\hline Soil net efflux & $R_{\mathrm{res}} / R_{\mathrm{SOM}}$ & 6.3 & 3.9 & 8.1 & 2.1 \\
\hline Net ecosystem $\mathrm{CO}_{2}$ flux & NEE & -2.0 & 0.3 & -0.2 & 4.4 \\
\hline \multicolumn{6}{|l|}{ Other GHG } \\
\hline $\mathrm{CH}_{4}$ flux & & -0.1 & 0.0 & -0.1 & 0.0 \\
\hline $\mathrm{N}_{2} \mathrm{O}$ flux & & 0.9 & 0.8 & 0.9 & 0.8 \\
\hline Total GHG flux balance & & -1.2 & 0.8 & 0.6 & 4.5 \\
\hline
\end{tabular}

plots (0.01 ha each) in a grid around the EC tower was shown to underestimate the BA compared to a measurement of all trees in a larger area $(90 \times 90 \mathrm{~m})$ around the EC tower and could be seen as a random error. We corrected this effect by applying a regression model and introducing a correction factor which was assigned an uncertainty corresponding to the coefficient of determination. Furthermore, the uncertainty induced by measurement errors was quantified by assuming an error in dbh and tree height of $5 \%$ and $10 \%$, respectively. The overall uncertainty of the annual tree growth amounted to almost $50 \%$ of the tree growth estimate: $3.9 \mathrm{t} \mathrm{C} \mathrm{ha}^{-1} \mathrm{yr}^{-1}$, of which the largest part is attributed to the measurement uncertainty.

\subsubsection{Approach 1: quantification of the NEE by eddy covariance}

The accuracy of the EC method depends upon a number of random and systematic errors related to sampling and theoretical issues as well as to site-specific matters such as limited fetch or topographic constraints. However, with a careful system design and the correct field installation, most errors are generally small. Based upon our own experience, errors related to gas analyzer calibration and signal dampening in tubes are both typically within 2-3\%, while errors due to sensor separation are less than $2 \%$ (Berger et al., 2001). Errors in EC measurements are generally considered to be less than $7 \%$ during daytime and less than $12 \%$ during nighttime as summarized by Baldocchi (2003). The natural variability of turbulent fluxes is in the order of 10-20\% (Wesely and Hart, 1985), but this and other random errors typically decrease with increasing size of the data set according to one over the square root of the number of samples or less for long-term averages (days, months, years) and are therefore probably very small.

In addition to random error, potential impacts of advection flows, uncertainties due to gap filling, and limited fetch conditions need to be considered. Advection occurs mainly during stable nighttime conditions, periods we have filtered out by the $u^{*}$ threshold method, which has been shown to be the best available approach (Aubinet et al., 2010). We estimated the uncertainty introduced by the gap filling to be $\pm 13 \mathrm{~g} \mathrm{C} \mathrm{m}^{-2}$ on an annual basis, which is in the same order of magnitude as the error estimated by Moffat et al. (2007) $\left( \pm 25 \mathrm{~g} \mathrm{C} \mathrm{m}^{-2} \mathrm{yr}^{-1}\right)$. Errors related to limitations in the fetch and topographical constraints are more difficult to quantify. In Sweden, afforested organic soils are often located in small valleys within a mosaic landscape, which means that they are not ideal for applying micrometeorological techniques. This does apply to the Skogaryd research catchment, but, since the source area was determined to be by $90 \%$ within $175 \mathrm{~m}$ in all directions of the tower and potentially moved further away only occasionally at nighttime (at maximum $250 \mathrm{~m}$ ), the potential influence of fetches of different vegetation and soil properties could only have been minor. Thus, considering the errors in calibration, potential random errors, gap filling and the fact that the footprint was well within the homogeneous part of the forest, we estimated the total error of the NEE measurements to be within $\pm 15 \%$, which gives a range of 1.7 to $2.3 \mathrm{tC} \mathrm{ha}^{-1} \mathrm{yr}^{-1}$. We chose a somewhat conservative uncertainty value in order to not overemphasize the precision of the eddy covariance data.

Whereas in approach 2 the respiration from SOM was determined according to chamber measurements (and balance calculations), in approach 1 respiration from SOM was 
determined as the residual between $\mathrm{NEE}_{\text {meas }}$ and tree growth. Both estimates differ by almost $30 \%$. Besides the errors induced by the respective flux components, the discrepancy in the average flux might be induced by a mismatch of the measurement period between flux measurements and tree growth estimation. Tree growth in spring is often initiated by re-mobilization of stored carbohydrates which were assimilated during the preceding autumn. This could imply that the measurement periods of NEE and chamber fluxes and tree growth do not overlap precisely, which would lead to a bias in the estimation of $R_{\text {res }}$. Barford et al. (2001) and Gough et al. (2008) assign this time lag as reason for the bad agreement between biometric and flux measurements for short time periods and for the good agreement when long periods are considered. Thus, when short-term periods are considered as in this study, this potential mismatch cannot be excluded.

\subsubsection{Approach 2: on the indirect quantification of the NEE}

The magnitude of $\mathrm{NEE}_{\text {calc }}$ in approach 2 is heavily based on precise quantification of the respiration from SOM $\left(R_{\mathrm{SOM}}\right)$. Due to the use of a trenching experiment, the measured soil $\mathrm{CO}_{2}$ efflux $\left(E_{\mathrm{CO}_{2}}\right)$ had to be corrected for the $\mathrm{CO}_{2}$ flux from the litter layer $\left(R_{\mathrm{LL}}\right)$ as well as the decay of roots $\left(R_{\text {decay }}\right.$, Table 1). This correction accounts for $38 \%$ of the measured efflux.

Uncertainties in the $\mathrm{CO}_{2}$ flux from the litter layer are difficult to evaluate. The assumption of a linear accumulation of litter since afforestation potentially induces a bias since year-to-year accumulation is likely to differ, and accumulation rather follows a linear curve after canopy closure. Calculating litter accumulation since canopy closure (assumed to occur 10, 15, 20, and $25 \mathrm{yr}$ after afforestation) changed the average annual accumulation between 0.34 and $0.9 \mathrm{tC} \mathrm{ha}^{-1} \mathrm{a}^{-1}$. Another source of uncertainty is induced by a potential measurement error in the litter layer $\mathrm{C}$ storage. However, assuming an error of $\pm 20 \%$ in the measured dry weight only had a minor effect on the calculated total respiration from the litter layer: $R_{\mathrm{LL}}$ ranged between $2.7 \pm 1.0$ and $2.77 \pm 1.0 \mathrm{tC} \mathrm{ha}^{-1} \mathrm{yr}^{-1}$.

An alternative method applied previously to quantify the respiration from SOM is to remove the litter layer before the experiment and install a mesh to exclude fresh litter (Mäkiranta et al., 2007). However, this method provokes artifacts due to changes in soil surface conditions, such as temperature, humidity and, consequently, priming effects (Kuzyakov, 2002; Mäkiranta et al., 2012).
Uncertainties in the correction terms for root decay were smaller and derive from potential errors in the applied root decomposition rates (see Table 1). Root decomposition is closely related to root turnover, which has been shown to be highly variable depending on tree species and also on sitespecific and climatic conditions (Finer et al., 2011; Brunner et al., 2012). We assessed this uncertainty by calculating the root decay for different decomposition rates as given by Ngao et al. (2007) and Chen et al. (2001). The calculated fine-root mass loss was $25 \%$ of the initial mass for the first year after trenching. Comparability to studies from the boreal zone is limited due to the scarcity of studies but is within the range reported in studies from other zones, e.g. Epron et al. (1999) for a beech forest in France (26\%) and Diaz-Pinez et al. (2010) for a mixed spruce forest in Austria (30\% in the first two years) (see also review by Subke et al., 2006). An alternative approach to estimate the impact of trenched roots was applied by Comstedt et al. (2011). Using a modeling approach based on a trenching experiment, they quantified the overestimation of the measured respiration due to decaying roots and mycelia to be $16 \%$ in the first year. However, their model uses the $\mathrm{CO}_{2}$ flux in the second year after trenching as a reference, assuming that the direct "decomposition effect" can be discounted that early. This is in sharp contrast to the results of Mäkiranta et al. (2010), who showed that the impact of decaying roots and mycelia can be considerable even in the third and fourth year after trenching. The estimation is, therefore, probably too low. Comstedt et al. (2011) furthermore pointed to the impact of trenching on the water table depth, which rises due to reduced root uptake so that microbial activity in the trenched plots may decrease. They concluded that this effect leads to an overestimation of the measured soil $\mathrm{CO}_{2}$ efflux of $29 \%$. In this study we did not observe any change of the water table depth after trenching, so this effect will have been minor.

\subsubsection{On $\mathrm{N}_{2} \mathrm{O}$ and $\mathrm{CH}_{4}$ fluxes}

The uncertainty estimate of the average annual $\mathrm{N}_{2} \mathrm{O}$ flux constituted about $85 \%$ of the flux itself. To this, the standard deviation between stations contributes more than $50 \%$, which points to the challenge of measuring $\mathrm{N}_{2} \mathrm{O}$ fluxes in such a heterogeneous environment like organic soils. Only a high measurement frequency and high spatial resolution could narrow this uncertainty. Also, the fortnightly measurement frequency might cause certain emission peaks not to be captured. However, this would mean that the actual $\mathrm{N}_{2} \mathrm{O}$ flux estimate of $11.1 \pm 9.3 \mathrm{~kg} \mathrm{~N}_{2} \mathrm{O} \mathrm{ha}^{-1}$ is too low. A further bias of the $\mathrm{N}_{2} \mathrm{O}$ flux estimate introduced by the fortnightly measurement frequency is the interpolation of measured fluxes for missing periods. We assessed this uncertainty by assuming a standard deviation of the daily gap-filled flux corresponding to the standard deviation of the data used to fill the gap which contributed about $40 \%$ to the total error. 
One concern with regard to the application of the chamber technique is that the technique itself creates artifacts (Livingston and Hutchinson, 1995), which are discussed in detail elsewhere (e.g. Pumpanen et al., 2004; Forbrich et al., 2010; Levy et al. 2011). A lack of fit of the regression model for the increase of gas concentration over time in the measurement chambers is considered to be the largest source of uncertainty, and especially the use of a linear model has been proposed to underestimate fluxes (Levy et al., 2011). Also, the use of a chamber without ventilation seems to underestimate fluxes (Christiansen et al., 2011). In contrast to these findings, a recent publication by Wang et al. (2013) demonstrated that $\mathrm{CH}_{4}$ fluxes as determined by the chamber method (without ventilation) and the eddy covariance agreed very well to each other. It must be emphasized that a potential bias caused by the assumption of a linear regression and the use of a chamber without ventilation again rather point to a potential underestimation of fluxes.

\subsection{Comparison of approaches and long-term GHG balance}

Although the average NEE determined by the two approaches differs by almost $2 \mathrm{tCha}^{-1}$, both approaches are consistent given the large uncertainty associated with $\mathrm{NEE}_{\text {calc }}$ of approach 2 . However, considering the uncertainty range, $\mathrm{NEE}_{\text {meas }}$ is always negative whereas $\mathrm{NEE}_{\text {calc }}$ could be positive or negative.

Due to the limitations of the methods applied for approach 2 as discussed above, we consider approach 1, the EC technique, to be the more reliable tool in this case to obtain precise estimates of the ecosystem $C$ budget. Nevertheless, comparability between the biometric tree growth measurements and the EC methodology to receive an estimate of $R_{\text {res }}$ is limited due to the time lag between $\mathrm{CO}_{2}$ assimilation by the trees and tree growth as discussed in Gough et al. (2008) and Barford et al. (2001). The study demonstrates that future research is needed to narrow uncertainties related to approach 2 , especially with regard to the determination of SOM respiration by the chamber technology. Although the approach is too uncertain to provide a precise quantification of the GHG budget, the analysis of the compartmental fluxes provides estimates of their magnitude and can improve process understanding.

Approach 1 indicates that the study site is a GHG sink of $-1.2 \pm 0.8 \mathrm{tC}_{\mathrm{eq}} \mathrm{ha}^{-1} \mathrm{a}^{-1}$ and that the $\mathrm{N}_{2} \mathrm{O}$ efflux offsets about $50 \%$ of the $\mathrm{C}$ sink strength (Table 4 ). However, the $\mathrm{N}_{2} \mathrm{O}$ flux estimate is associated with high uncertainty induced by the heterogeneous soil conditions and gap filling. In comparison to the previous and following year, fluxes in 2008 were clearly higher, though this could be attributed to climatic conditions. Additional biases, which are difficult to assess, would lead rather to an underestimation than an overestimation of the flux.
It must be stressed that we only present measurements for a single year so that no evidence can be provided to elucidate the long-term GHG budget of this site. A few studies, however, can give some indication: using snap-shot measurements and modeling, Hargreaves et al. (2003) showed that young forests of about 4 to $8 \mathrm{yr}$ act as a net $\mathrm{C}$ source but then transform into $\mathrm{C}$ sinks when the $\mathrm{C}$ accumulation in trees exceeds the soil $\mathrm{C}$ losses due to decomposition. Gower et al. (1996) estimated the age of boreal evergreen forests associated with maximum biomass production to about $60-70 \mathrm{yr}$. With increasing age, i.e. after canopy closure, the $\mathrm{C}$ sink potential declines again because of the decomposition of harvest residues and the lower $\mathrm{C}$ accumulation by trees (Gower et al., 1996; Ågren and Hyvönen, 2003; Black and Gallagher, 2010). As a consequence, the overall net GHG uptake of the investigated site in the Skogaryd research catchment is likely to be limited to a rather short time when the forest is at its maximum productivity. Furthermore, the observed and estimated $\mathrm{N}_{2} \mathrm{O}$ and $\mathrm{CO}_{2}$ fluxes from the soil range at the upper end of or are higher than reported values. This implies that the overall GHG budget is very sensitive to changes in the tree $\mathrm{C}$ accumulation and that minor changes in the $\mathrm{C}$ assimilation could turn the ecosystem into a GHG source.

Afforested, nutrient-rich organic soils might therefore be net GHG emitters for a rather long period. Emissions of $\mathrm{CO}_{2}$ and $\mathrm{N}_{2} \mathrm{O}$ can be high, as has been shown in previous studies (e.g. von Arnold et al., 2005b; Alm et al., 2007) and can compensate or exceed the $\mathrm{C}$ accumulation in trees. The afforestation of former agricultural soils in order to turn the ecosystem into an overall long-term GHG sink might therefore not be an effective strategy.

\section{Conclusions}

We investigated the total GHG budget of a spruce forest on a nutrient-rich organic soil, using the chamber technique to quantify $\mathrm{N}_{2} \mathrm{O}$ and $\mathrm{CH}_{4}$ fluxes and applying two approaches to determine the $\mathrm{C}$ balance: an indirect balance calculation approach based on chamber measurements and the direct measurement of the NEE by eddy covariance. Due to accumulated uncertainties that remain to be resolved using the indirect method, the direct method was considered to be the more reliable tool for obtaining precise estimates of the $\mathrm{C}$ and the overall GHG budget. According to the EC method, the site is currently a GHG sink due to the high C uptake by the actively growing forest; however, this is offset to a large extent by $\mathrm{N}_{2} \mathrm{O}$ emissions. We conclude that during peak forest production, the nutrient-rich forest ecosystem is a GHG sink, but it will probably be a GHG source over the remaining time, hence contributing to global warming. According to Klemedtsson et al. (2005) and Ernfors et al. (2008), organic soils with a low $\mathrm{C}: \mathrm{N}$ ratio $(<25)$, as typical for former agricultural soils, cover about $60 \%$ of the total area of drained organic forestland in Sweden, so that the GHG balance of these 
Table A1. Overview of the instrumentation applied at the Skogaryd research catchment: measured environmental parameter or technical equipment, height of the instrument at the eddy flux tower or soil depth of the instrument, information on applied software or instrument, and manufacturer.

\begin{tabular}{|c|c|c|c|}
\hline $\begin{array}{l}\text { Parameter / technical } \\
\text { equipment }\end{array}$ & $\begin{array}{l}\text { Instrument } \\
\text { height / depth } \\
\text { (m) }\end{array}$ & Instrument & Manufacturer \\
\hline \multicolumn{4}{|c|}{ Ground abiotic data: recorded every $30 \mathrm{~min}$} \\
\hline Air temperature & 1.5 & Campbell 107 temperature probe & $\begin{array}{l}\text { Campbell Scientific, } \\
\text { Logan UT, USA }\end{array}$ \\
\hline Radiation shield & & UT12VA 12-Plate Radiation Shield & $\begin{array}{l}\text { Campbell Scientific, } \\
\text { Logan UT, USA }\end{array}$ \\
\hline Soil temperature & $\begin{array}{l}-0.05 \\
\text { to }-0.6\end{array}$ & $\begin{array}{l}\text { Copper-constantan thermocouples, } \\
\text { temperature probes } 107\end{array}$ & $\begin{array}{l}\text { Campbell Scientific, } \\
\text { Logan UT, USA }\end{array}$ \\
\hline Water table depth & & CS-420-L submersible pressure transducer & $\begin{array}{l}\text { Campbell Scientific, } \\
\text { Logan UT, USA }\end{array}$ \\
\hline Logger & & CR10X logger, AM16/32A multiplexer & $\begin{array}{l}\text { Campbell Scientific, } \\
\text { Logan UT, USA }\end{array}$ \\
\hline \multicolumn{4}{|l|}{ EC flux system } \\
\hline $\mathrm{CO}_{2}, \mathrm{H}_{2} \mathrm{O}$ concentration & 27 & Infrared gas analyzer LI-6262 & $\begin{array}{l}\text { Li-Cor Inc., } \\
\text { Lincoln USA }\end{array}$ \\
\hline 3-D wind speed, air temperature & 27 & Sonic anemometer Gill R3 & Solent, UK \\
\hline \multicolumn{4}{|c|}{ Meteorological data: recorded every $10 \mathrm{~min}$} \\
\hline Air temperature, air humidity & 22 & $\begin{array}{l}\text { MP101A probe in } \\
\text { ventilated radiation shield }\end{array}$ & Rotronic, USA \\
\hline Global radiation & 27 & pyranometer SP-series & $\begin{array}{l}\text { Apogee SP, } \\
\text { Logan, USA }\end{array}$ \\
\hline Net radiation & 27 & Net radiometer NR-Lite & $\begin{array}{l}\text { Kipp \& Zonen, Delft, } \\
\text { Netherlands }\end{array}$ \\
\hline PAR & 27 & PAR sensor SQ-series & $\begin{array}{l}\text { Apogee SP, } \\
\text { Logan, USA }\end{array}$ \\
\hline Logger & & CR10X logger & $\begin{array}{l}\text { Campbell Scientific, } \\
\text { Logan UT, USA }\end{array}$ \\
\hline
\end{tabular}

\begin{tabular}{|c|c|c|}
\hline \multicolumn{3}{|c|}{ Soil respiration: automatic closed chambers $\left(0.24 \mathrm{~m}^{3}\right)$, ventilated by fan, automatic lid closure before measurement } \\
\hline Actuator for lid opening & Linear Actuator LA12 & $\begin{array}{l}\text { LINAK A/S, Nordborg, } \\
\text { Denmark }\end{array}$ \\
\hline Logger system & $\begin{array}{l}\text { CR10X logger, AM16/32A multiplexer, SDM- } \\
\text { CD16 relay control port module }\end{array}$ & $\begin{array}{l}\text { Campbell Scientific, } \\
\text { Logan UT, USA }\end{array}$ \\
\hline Infrared gas analyzer & SBA-4 OEM CO2 Analyzer & $\begin{array}{l}\text { PP Systems, } \\
\text { Amesbury MA, USA }\end{array}$ \\
\hline \multicolumn{3}{|c|}{$\begin{array}{l}\mathrm{N}_{2} \mathrm{O} \text { and } \mathrm{CH}_{4} \text { flux: dark chamber technique, gas sampling } 4,8,16 \text {, and } 32 \mathrm{~min} \text { after chamber closure by means of extracting a } \\
\text { gas sample with a syringe inserted into a rubber septum in the chamber lid. Chamber volume: } 0.017 \mathrm{~m}^{3}\end{array}$} \\
\hline $\begin{array}{l}\text { Determination of gas } \\
\text { concentration of samples }\end{array}$ & Varian 3400 gas chromatograph & $\begin{array}{l}\text { Agilent Technologies Inc., } \\
\text { Santa Clara CA, USA }\end{array}$ \\
\hline Flux calculation & STAR & Varian \\
\hline
\end{tabular}

sites is of major importance for the national GHG inventory. Therefore, the long-term GHG sink potential of these sites must be seriously questioned and it is recommended that future GHG mitigation strategies take site-specific properties into account.
Acknowledgements. Financial support came from the Swedish Research Council for Environment, Agricultural Sciences and Spatial Planning (FORMAS), the strategic research area BECC (Biodiversity and Ecosystem services in a Changing Climate, www.cec.lu.se/research/becc), the Linnaeus Centre LUCCI (Lund University Centre for studies of Carbon Cycle and Climate Ineractions) as well as the NitroEurope IP under the EC 6th Framework Programme (contract no. 017841). We would like to thank the two anonymous reviewers, as well as Annette Freiberger and Paavo 
Ojanen for their constructive remarks, which considerably helped to improve the quality of the paper. We thank Johannes Edvardsson, Lund University, for supplying the data on tree age and David Allbrand, Gothenburg University, for his assistance in the field.

Edited by: P. Stoy

\section{References}

Ågren, G. I. and Hyvönen, R.: Changes in carbon stores in Swedish forest soils due to increased biomass harvest and increased temperatures analysed with a semi-empirical model, Forest. Ecol. Manage., 174, 25-37, 2003.

Alm, J., Shurpali, N., Minkkinen, K., Aro, L., Hytönen, J., Laurila, T., Lohila, A., Maljanen, M., Martikainen, P., Mäkiranta, P., Penttila, T., Saarnio, S., Silvan, N., Tuittila, E., and Laine, J.: Emission factors and their uncertainty for the exchange of $\mathrm{CO}_{2}$, $\mathrm{CH}_{4}$ and $\mathrm{N}_{2} \mathrm{O}$ in Finnish managed peatlands, Boreal. Environ. Res., 12, 191-209, 2007.

Aubinet, M., Feigenwinter, C., Heinesch, B., Bernhofer, C., Canepa, E., Lindroth, A., Montagnani, L., Rebmann, C., Sedlak, P., and Van Gorsel, E.: Direct advection measurements do not help to solve the night-time $\mathrm{CO}_{2}$ closure problem: Evidence from three different forests, Agr. Forest Meteorol., 150, 655-664, 2010.

Baldocchi, D. D.: Assessing the eddy covariance technique for evaluating carbon dioxide exchange rates of ecosystems: past, present and future, Glob. Change Biol., 9, 479-492, 2003.

Barford, C. C., Wofsy, S. C., Goulden, M. L., Munger, J. W., Hammond Pyle, E., Urbanski, S. P., Hutyra, L., Saleska, S. R., Fitzjarrald, D., and Moore, K.: Factors controlling long- and short term sequestration of atmospheric $\mathrm{CO}_{2}$ in a mid-latitude forest, Science, 294, 1688-1691, 2001.

Berg, B. and C. McClaugherty (Eds): Plant Litter: Decomposition, Humus Formation, Carbon Sequestration. Springer, 2 Edn., Berlin, Germany, 2008.

Berger, B. W., Davis, K. J., Yi, C., Bakwin, P. S., and Zhao, C.: Long-term carbon dioxide fluxes from a very tall tower in a northern forest: Part I. Flux measurement methodology, J. Atmos. Ocean Tech., 18, 529-542, 2001.

Berglund, O. and Berglund, K.: Distribution and cultivation intensity of agricultural peat and gyttja soils in Sweden and estimation of greenhouse gas emissions from cultivated peat soils, Geoderma, 154, 173-180, 2010.

Black, K. and Gallagher, G.: The greenhouse gas balance of peatland forest, COFORD Connects, Forest. Environ., 11, Dublin, Ireland, 2010

Brunner, I., Bakker, M., Björk, R., Hirano, Y., Lukac, M., Aranda, X., Børja, I., Eldhuset, T., Helmisaari, H., Jourdan, C., Konopka, B., Lopez, B., Miguel Perez, C., Persson, H., and Ostonen, I.: Fine-root turnover rates of European forests revisited: an analysis of data from sequential coring and ingrowth cores, Plant. Soil, 362, 357-372, 2013.

Chave, J., Condit, R., Aguliar, S., Hernandez, A., Lao, S., and Perez, R.: Error propagation and scaling for tropical forest biomass estimates, Phil. T. R. Soc. Lond. B, 359, 409-420, 2004.

Chen, H., Harmon, M. E., and Griffiths, R. P.: Decomposition and nitrogen release from decomposing woody roots in coniferous forests of the Pacific Northwest: a chronosequence approach, Can. J. Forest Res., 31, 246-260, 2001.

Christiansen, J. R., Korhonen, J. F. J., Juszczak, R., Giebels, M., and Pihlatie, M.: Assessing the effects of chamber placement, manual sampling and headspace mixing on $\mathrm{CH}_{4}$ fluxes in a laboratory experiment, Plant. Soil, 343, 171-185, 2011.

Comstedt, D., Boström, B., and Ekblad, A.: Autotrophic and heterotrophic soil respiration in a Norway spruce forest: estimating the root decomposition and soil moisture effects in a trenching experiment, Biogeochemistry, 104, 121-132, 2011.

Couwenberg, J.: Greenhouse gas emission from managed peat soils: is the IPCC resporting realistic?, Mires. Peat., 8, 1-10, 2011.

Dewar, R. C., Tarvainen, L., Parker, K., Wallin, G., and McMurtrie, R. E.: Why does leaf nitrogen decline within tree canopies less rapidly than light? An explanation from optimization subject to a lower bound on leaf mass per area, Tree Physiol, 32, 520-534, 2012.

Diaz-Pinez, E., Schindlbacher, A., Pfeffer, M., Jandl, R., Zechmeister-Boltenstern, S., and Rubio, A.: Root trenching: a useful tool to estimate autotrophic soil respiration? A case study in an Austrian mountain forest, Eur. J. For. Res., 129, 101-109, 2010.

Dunn, A., Barford, C., Wofsy, S., Goulden, M., and Daube, B.: A long-term record of carbon exchange in a boreal black spruce forest: means, responses to interannual variability, and decadal trends, Glob. Change Biol., 13, 577-590, 2007.

Dyson, K. E., Billett, M. F., Dinsmore, K. J., Harvey, F., Thomson, A. M., Piirainen, S., and Kortelainen, P.: Release of aquatic carbon from two peatland catchments in E. Finland during the spring snowmelt period, Biogeochemistry, 103, 125-142, 2011.

Ernfors, M.: Greenhouse gas fluxes between drained forested peatlands and the atmosphere - influence of nutrient status and wood ash fertilization. PhD thesis, University of Gothenburg, Gothenburg, Sweden, 2009.

Ernfors, M., von Arnold, K., Stendahl, J., Olsson, M., and Klemedtsson, L.: Nitrous oxide emissions from drained organic forest soils - an up-scaling based on $\mathrm{C}: \mathrm{N}$ ratios, Biogeochemistry, 89, 29-41, 2008.

Ernfors, M., Rütting, T., and Klemedtsson, L.: Increased nitrous oxide emissions from a drained organic forest soil after exclusion of ectomycorrhizal mycelia, Plant. Soil, 343, 161-170, 2011.

Finer, L., Ohashi, M., Noguchi, K., and Hirano, Y.: Fine root production and turnover in forest ecosystems in relation to stand and environmental characteristics, Forest Ecol. Manage., 262, 20082023, 2011.

Flanagan, L. B. and Syed, K. H.: Stimulation of both photosynthesis and respiration in response to warmer and drier conditions in a boreal peatland ecosystem, Glob. Change Biol., 17, 2271-2287, 2011.

Forbrich, I., Kutzbach, L., Hormann, A., and Wilmking, M.: A comparison of linear and exponential regression for estimating diffusive $\mathrm{CH}_{4}$ fluxes by closed-chambers in peatlands, Soil. Biol Biochem., 4, 407-415, 2010.

Forster, P., Ramaswamy, V., Artaxo, P., Berntsen, T., Betts, R., Fahey, D., Haywood, J., Lean, J., Lowe, D., Myhre, G., Nganga, J., Prinn, R., Raga, G., Schulz, M., and van Dorland, R.: Changes in Atmospheric Constituents and in Radiative Forcing, In: Climate Change 2007: The Physical Science Basis. Contribution of Working Group I to the Fourth Assessment Report of the Inter- 
governmental Panel on Climate Change, edited by: Solomon, S., Qin, D., Manning, M., Chen, Z., Marquis, M., Averyt, K., Tignor, M., and Miller, H., Cambridge University Press, Cambridge, UK, 133-234, 2007.

Gower, S.T., McMurtrie, R. E., and Murty, D.: Aboveground net primary production decline with stand age: potential causes, Trees, 11, 378-382, 1996.

Gough, C. M., Vogel, C. S., Schmid, H. P., Su, H.-B., and Curtis, P. S.: Multi-year convergence of biometric and meteorological estimates of forest carbon storage, Agr. For. Met., 148, 158-170, 2008.

Grelle, A. and Lindroth, A.: Eddy-correlation system for longterm monitoring of fluxes of heat, water vapour and $\mathrm{CO}_{2}$, Glob. Change Biol., 2, 297-307, 1996.

Grelle, A., Lundberg, A., Lindroth, A., Morén, A.-S., and Cienciala, E.: Evaporation components of a boreal forest: Variations during the growing season, J. Hydrol., 197, 70-87, 1997.

Haei, M., Oquist, M. G., Buffam, I., Ågren, A., Blomkvist, P., Bishop, K., Lofvenius, M. O., and Laudon, H.: Cold winter soils enhance dissolved organic carbon concentrations in soil and stream water, Geophys. Res. Lett., 37, L08501, 2010.

Hanson, P. J., Edwards, N. T., Garten, C. T., and Andrews, J. A.: Separating root and soil microbial contributions to soil respiration: A review of methods and observations, Biogeochemistry, 48, 115-146, 2000.

Hargreaves, K., Milne, R., and Cannell, M.: Carbon balance of afforested peatland in Scotland, Forestry, 76, 299-317, 2003.

He, L., Chen, J. M., Pan, Y., Birdsey, R., and Kattge, J.: Relationships between net primary productivity and forest stand age in U.S. forests, Glob. Biogeochem. Cycles, 26, GB3009, 2012.

Höper, H.: Carbon and nitrogen mineralization rates in German agriculturally used fenlands, in: Wetlands in Central Europe: Soil organisms, soil ecological processes and trace gas emissions, edited by: Broll, G., Merbach, W. and Pfeiffer, E. M., Springer, Berlin, Germany, 149-164, 2002.

Huttunen, J., Nykanen, H., Martikainen, P., and Nieminen, M.: Fluxes of nitrous oxide and methane from drained peatlands following forest clear-felling in southern Finland, Plant. Soil, 255, 457-462, 2003.

Jalkanen, A., Mäkipää, G., Ståhl, G., Lehtonen, A., and Petersson, H.: Estimation of the biomass stock of trees in Sweden: comparison of biomass equations and age-dependent biomass expansion factors, Ann. For. Sci., 62, 845-851, 2005.

Jenkins, J. C., Chojnacky, D. C., Heath, L. S., and Birdsey, R. A.: National-scale biomass estimators for United States tree species, Forest Sci., 49, 12-35, 2003.

Jungkunst, H. F. and Fiedler, S.: Latitudinal differentiated water table control of carbon dioxide, methane and nitrous oxide fluxes from hydromorphic soil: feedbacks to climate change, Glob. Change Biol., 13, 2668-2683, 2007.

Kaimal, J. C., Wyngaard, J. C., Izumi, Y., and Coté, O. R.: Spectral Characteristics of Surface-Layer Turbulence, Q. J. Roy. Meteor. Soc., 98, 563-589, 1972.

Kasimir-Klemedtsson, Å., Klemedtsson, L., Berglund, K., Martikainen, P., Silvola, J., and Oenema, O.: Greenhouse gas emissions from farmed organic soils: a review, Soil Use. Manage., 13, 245-250, 1997.
Kasimir Klemedtsson, Å., Weslien, P., and Klemedtsson, L.: Methane and nitrous oxide fluxes from a farmed Swedish Histosol, Eur. J. Soil Sci., 60, 321-331, 2009.

Klemedtsson, L., von Arnold, K., Weslien, P., and Gundersen, P.: Soil $\mathrm{CN}$ ratio as a scalar parameter to predict nitrous oxide emissions, Glob. Change Biol., 11, 1142-1147, 2005.

Klemedtsson, L., Ernfors, M., Björk, R., Weslien, P., Rütting, T., Crill, P., and Sikström, U.: Reduction of greenhouse gas emissions by wood ash application to a Picea abies (L.) Karst. forest on a drained organic soil, Eur. J. Soil Sci., 61, 734-744, 2010.

Köhler, S. J., Buffam, I., Laudon, H., and Bishop, K. H.: Climates control of intra-annual and interannual variability of total organic carbon concentration and flux in two contrasting boreal landscape elements, J. Geophys. Res.-Biogeo., 113, G03012, 2008.

Kuzyakov, Y.: Review: Factors affecting rhizosphere priming effects, J. Plant. Nutr. Soil. Sc., 165, 382-396, 2002.

Laiho, R. and Finer, L.: Changes in root biomass after water-level drawdown on pine mires in southern Finland, Scand J. Forest. Res., 11, 251-260, 1996.

Laudon, H., Köhler, S. and Buffam, I.: Seasonal TOC export from seven boreal catchments in northern Sweden, Aquat Sci, 66, 223 230, 2004.

Levy, P. E., Gray, A., Leeson, S. R., Gaiawyn, J., Kelly, M. P. C., Cooper, M. D. A., Dinsmore, K. J., Jones, S. K., and Sheppard, L. J.: Quantification of uncertainty in trace gas fluxes measured by the static chamber method, Eur. J. Soil Sci., 62, 811-821, 2011.

Lindroth, A., Klemedtsson, L., Grelle, A., Weslien, P., and Langvall, O.: Measurement of net ecosystem exchange, productivity and respiration in three spruce forests in Sweden shows unexpectedly large soil carbon losses, Biogeochemistry, 89, 43-60, 2008.

Livingston, G. P. and Hutchingson, G. L.: Enclosure-based measurement of trace gas exchange: application and sources of error in: Methods in Ecology-Biogenic Trace Gases: Measuring Emissions from Soil and Water, edited by: Matson, P. A. and Harriss, R. C., Blackwell, London, U.K., 14-51, 1995.

Lohila, A., Laurila, T., Aro, L., Aurela, M., Tuovinen, J. P., Laine, J., Kolari, P., and Minkkinen, K.: Carbon dioxide exchange above a 30-year-old Scots pine plantation established on organic-soil cropland, Boreal Environ. Res., 12, 141-157, 2007.

Lohila, A., Minkkinen, K., Aurela, M., Tuovinen, J. P., Penttila, T., Ojanen, P., and Laurila, T.: Greenhouse gas flux measurements in a forestry-drained peatland indicate a large carbon sink, Biogeosciences, 8, 3203-3218, 2011, http://www.biogeosciences.net/8/3203/2011/.

Maljanen, M., Liikanen, A., Silvola, J., and Martikainen, P.: Methane fluxes on agricultural and forested boreal organic soils, Soil. Use Manage., 19, 73-79, 2003a.

Maljanen, M., Liikanen, A., Silvola, J., and Martikainen, P.: Nitrous oxide emissions from boreal organic soil under different landuse, Soil Biol. Biochem., 35, 689-700, 2003b.

Maljanen, M., Komulainen, V. M., Hytönen, J., Martikainen, P., and Laine, J.: Carbon dioxide, nitrous oxide and methane dynamics in boreal organic agricultural soils with different soil characteristics, Soil. Biol Biochem., 36, 1801-1808, 2004.

Maljanen, M., Hytönen, J., Mäkiranta, P., Alm, J., Minkkinen, K., Laine, J., and Martikainen, P. J.: Greenhouse gas emissions from cultivated and abandoned organic croplands in Finland, Boreal Environ. Res., 12, 133-140, 2007. 
Maljanen, M., Sigurdsson, B., Guomundsson, J., Oskarsson, H., Huttunen, J., and Martikainen, P.: Greenhouse gas balances of managed peatlands in the Nordic countries - present knowledge and gaps, Biogeosciences, 7, 2711-2738, 2010, http://www.biogeosciences.net/7/2711/2010/.

Marklund, L.: Biomassfunktioner för tall, gran och björk i Sverige, Rapporter Skog, 45, Sveriges Lantbruksuniversitet, Sweden, 173, 1988.

Martikainen, P., Nykänen, H., Crill, P., and Silvola, J.: Effect of a lowered water-table on nitrous-oxide Fluxes from Northern peatlands, Nature, 366, 51-53, 1993.

McRoberts, R. E., Hahn, J. T., Hefty, G. J., and Van Cleve, J. R.: Variation in forest inventory field measurements, Can. J. For. Res., 24, 1766-1770, 1994.

Mehtätalo, L.: A longitudinal height-diameter model for Norway spruce in Finland, Can. J. For. Res., 34, 131-140, 2004.

Melson, S. L., Harmon, M. E., Fried, J. S., and Domingo, J. B.: Estimates of live-tree carbon stores in the Pacific Northwest are sensitive to model selection, Carbon Balance Manage, 6, 2-16, 2011.

Minkkinen, K. and Laine, J.: Vegetation heterogeneity and ditches create spatial variability in methane fluxes from peatlands drained for forestry, Plant. Soil, 285, 289-304, 2006.

Minkkinen, K., Vasander, H., Jauhiainen, S., Karsisto, M., and Laine, J.: Post-drainage changes in vegetation composition and carbon balance in Lakkasuo mire, Central Finland, Plant. Soil, 207, 107-120, 1999.

Minkkinen, K., Laine, J., and Hokka, H.: Tree stand development and carbon sequestration in drained peatland stands in Finland a simulation study, Silva Fenn, 35, 55-69, 2001.

Minkkinen, K., Korhonen, R., Savolainen, I., and Laine, J.: Carbon balance and radiative forcing of Finnish peatlands 1900-2100 the impact of forestry drainage, Glob Change Biol, 8, 785-799, 2002.

Mäkiranta, P., Hytönen, J., Aro, L., Maljanen, M., Pihlatie, M., Potila, H., Shurpali, N., Laine, J., Lohila, A., Martikainen, P., and Minkkinen, K.: Soil greenhouse gas emissions from afforested organic soil croplands and cutaway peatlands, Boreal Environ. Res., 12, 159-175, 2007.

Mäkiranta, P., Minkkinen K., Hytönen, J., and Laine, J.: Factors causing temporal and spatial variation in heterotrophic and rhizospheric components of soil respiration in afforested organic croplands in Finland, Soil Biol. Biochem., 40, 1592-1600, 2008.

Mäkiranta, P., Riutta, T., Penttila, T., and Minkkinen, K.: Dynamics of net ecosystem $\mathrm{CO}_{2}$ exchange and heterotrophic soil respiration following clearfelling in a drained peatland forest, Agr. For. Meteorol., 150, 1585-1596, 2010.

Mäkiranta, P., Laiho, R., Penttilä, T., and Minkkinen, K.: The impact of logging residue on soil GHG fluxes in a drained peatland forest, Soil Biol. Biochem., 48, 1-9, 2012.

Moffat, A. M., Papale, D., Reichstein, M., Hollinger, D. Y., Richardson, A. D., Barr, A. G., Beckstein, C., Braswel, B. H., Churkina, G., Desai, A. R., Falge, E., Gove, J. H., Heimann, M., Hui, D., Jarvis, A. J., Kattge, J., Noormets, A., and Stauch, V. J.: Comprehensive comparison of gap-filling techniques for eddy covariance net carbon fluxes, Agr. For. Meteorol., 147, 209-232, 2007.

Ngao, J., Longdoz, B., Granier, A., and Epron, D.: Estimation of autotrophic and heterotrophic components of soil respiration by trenching is sensitive to corrections for root decomposition and changes in soil water content, Plant Soil., 301, 99-110, 2007.

Nilsson, M., Sagerfors, J., Buffam, I., Laudon, H., Eriksson, T., Grelle, A., Klemedtsson, L., Weslien, P., and Lindroth, A.: Contemporary carbon accumulation in a boreal oligotrophic minerogenic mire - a significant sink after accounting for all C-fluxes, Glob. Change Biol., 14, 2317-2332, 2008.

Nykänen, H., Alm, J., Silvola, J., Tolonen, K., and Martikainen, P.: Methane fluxes on boreal peatlands of different fertility and the effect of long-term experimental lowering of the water table on flux rates, Global Biogeochem. Cy., 12, 53-69, 1998.

Ojanen, P., Minkkinen, K., Alm, J., and Penttila, T.: Soilatmosphere $\mathrm{CO}_{2}, \mathrm{CH}_{4}$ and $\mathrm{N}_{2} \mathrm{O}$ fluxes in boreal forestry-drained peatlands, Forest Ecol. Manage., 260, 411-421, 2010.

Ojanen, P., Minkkinen, K., Lohila, A., Badorek, T., and Penttila, T. Chamber measured soil respiration: A useful tool for estimating the carbon balance of peatland forest soils?, Forest Ecol. Manage., 277, 132-140, 2012.

Öquist, M. G., Wallin, M., Seibert, J., Bishop, K., and Laudon, H.: Dissolved inorganic carbn export across soil / stream interface and its fate in a boreal headwater streams, Environ. Sci. Technol., 43, 7364-7369, 2009

Pihlatie, M., Kiese, R., Brüggemann, N., Butterbach-Bahl, K., Kieloaho, A., Laurila, T., Lohila, A., Mammarella, I., Minkkinen, K., Penttila, T., Schönborn, J., and Vesala, T.: Greenhouse gas fluxes in a drained peatland forest during spring frost-thaw event, Biogeosciences, 7, 1715-1727, 2010, http://www.biogeosciences.net/7/1715/2010/.

Pumpanen, J., Kolari, P., Ilvesniemi, H., Minkkinen, K., Vesala, T., Niinistö, S., Lohila, A., Larmola, T., Morero, M., Pihlatie, M., Janssens, I., Yuste, J. C., Grünzweig, J. M., Reth, S., Subke, J. A., Savage, K., Kutsch, W., Østreng, G., Ziegler, W., Anthoni, P., Lindroth, A., and Hari, P.: Comparison of different chamber techniques for measuring soil $\mathrm{CO}_{2}$ efflux, Agr. For. Meteorol., 123, 159-176, 2004.

Rantakari, M., Mattsson, T., Kortelainen, P., Piirainen, S., Finer, L., and Ahtiainen, M.: Organic and inorganic carbon concentrations and fluxes from managed and unmanaged boreal first-order catchments, Sci. Total Environ., 408, 1649-1658, 2010.

Schlesinger, W. H. and Andrews, J. A.: Soil respiration and the global carbon cycle, Biogeochemistry, 48, 7-20, 2000.

Schmid, H. P.: Source areas for scalars and scalar fluxes, Bound-Lay Meteorol 67, 293-318, 1994.

Schmid, H. P.: Footprint modeling for vegetation atmosphere exchange studies: a review and perspective, Agr. For. Meteorol. 113, 159-183, 2002.

Subke, J.-A., Inglima, I., and Cotrufo, F.: Trends and methodological impacts in soil $\mathrm{CO}_{2}$ efflux partitioning: a metaanalytical review, Glob. Change Biol., 12, 921-943, 2006.

Vickers, D., Irvine, J., Martin, J. G., and Law, B. E.: Nocturnal subcanopy flow regimes and missing carbon dioxide, Agr. For. Meteorol., 152, 101-108, 2012.

von Arnold, K.: Forests and Greenhouse gases - Fluxes of $\mathrm{CO}_{2}$, $\mathrm{CH}_{4}$ and $\mathrm{N}_{2} \mathrm{O}$ from drained forests on organic soils, $\mathrm{PhD}$ thesis, Linköping Studies in Arts and Science, 302, Linköping University, Sweden, 2004.

von Arnold, K., Hånell, B., Stendahl, J., and Klemedtsson, L.: Greenhouse gas fluxes from drained organic forestland in Sweden, Scand J. For. Res., 20, 400-411, 2005a. 
von Arnold, K., Weslien, P., Nilsson, M., Svensson, B. and Klemedtsson, L.: Fluxes of $\mathrm{CO}_{2}, \mathrm{CH}_{4}$ and $\mathrm{N}_{2} \mathrm{O}$ from drained coniferous forests on organic soils, Forest Ecol Manag, 210, 239254, 2005b.

Wallander, H., Ekblad, A., Godbold, D., Johnson, D., Bahr, A., Baldrian, P., Björk, R., Kieliszewska-Rokicka, B., Kjøller, R., Kraigher, H., Plassard, C., and Rudawska, M.: Evaluation of methods to estimate production, biomass and turnover of ectomycorrhizal mycelium in forests soils - A review, Soil Biol. Biochem., 57, 1034-1047, 2013.

Wallin, G., Linder, S., Lindroth, A., Rantfors, M., Flemberg, S., and Grelle, A.: Carbon dioxide exchange in Norway spruce at the shoot, tree and ecosystem scale, Tree Physiol., 21, 969-976, 2001.

Wallin, M., Buffam, I., Öquist, M., Laudon, H., and Bishop, K.: Temporal and spatial variability of dissolved inorganic carbon in a boreal stream network: concentrations and downstream fluxes, J. Geophys. Res., 115, G02014, 2010.

Wang, J. M., Murphy, J. G., Geddes, J. A., Winsborough, C. L., Basiliko, N., and Thomas, S. C.: Methane fluxes measured by eddy covariance and static chamber techniques at a temperate forest in central Ontario, Canada, Biogeosciences, 10, 43714382, 2013, http://www.biogeosciences.net/10/4371/2013/.

Watson, R. T., Noble, I. R., Bolin, B., Ravidranath, N. H., Verardo, D. J., and Dokken, D. J.: Land use, land use change, and forestry. A special report of the IPCC, Cambridge University Press, Cambridge, U.K., 2000.
Webb, E. K., Pearman, G. I., and Leuning, R.: Correction of flux measurements for density effects due to heat and water vapour transfer, Q. J. Roy. Meterol. Soc., 106, 85-100, 1980.

Wesely, M. L. and Hart, R. L.: Variability of short term eddy-correlation estimates of mass exchange, in: The ForestAtmosphere Interaction, Proceedings of the Forest Environmental Measurements Conference held at Oak Ridge, Reidel Publishing Company, Dordrecht, The Netherlands, 591-612, 1985.

White, M. A., Thornton, P. E., Running, S. W., and Nemani, R. R.: Parameterization and sensitivity analysis of the BIOME-BGC terrestrial ecosystem model: net primary production controls, Earth Interact, 4, 1-85, 2000.

Wilson, K., Goldstein, A., Falge, E., Aubinet, M., Baldocchi, D., Berbiger, P., Bernhofer, C., Ceulemans, R., Dolman, H., Field, C., Grelle, A., Ibrom, A., Law, B. E., Kowalski, A., Meyers, T., Moncrieff, J., Monson, R., Oechel, W., Tenhunen, J., Valentini, R., and Vema, S.: Energy balance closure at FLUXNET sites, Agr. For. Met., 113, 223-243, 2002.

Yamulki, S., Anderson, R., Peace, A., and Morison, J.: Soil $\mathrm{CO}_{2}$, $\mathrm{CH}_{4}$, and $\mathrm{N}_{2} \mathrm{O}$ fluxes from an afforested lowland raised peatbog in Scotland: implications for drainage and restoration, Biogeosciences, 10, 1051-1065, 2013, http://www.biogeosciences.net/10/1051/2013/. 